\title{
O Uso Retórico do Antigo Testamento na Carta aos Colossenses*
}

\author{
Waldecir Gonzaga ${ }^{a}$ \\ Pontificia Universidad Católica de Río de Janeiro, Brasil \\ http://orcid.org/0000-0001-5929-382X \\ Doaldo Ferreira Belem \\ Instituto Bíblico Ebenezer, Brasil \\ http:/ / orcid.org/0000-0003-1431-0125
}

RECEIVED: 20-11-19. ACCEPTED: 14-03-2020

Resumo: A Carta aos Colossenses, além da questáo se de fato é ou não deuteropaulina, entrou no centro do debate sobre a Metodologia do uso da Antigo Testamento pelo Novo Testamento. Se durante muitos anos foi considerada uma das poucas cartas do corpus paulinum a não possuir nenhuma citação do Antigo Testamento, Beale conseguiu encontrar várias alusôes. Foster criticou a metodologia utilizada em Colossenses, o que mereceu uma resposta por parte de Beale. Entretanto, Beetham confirmou o uso detectado por Beale, especificando a diferenciação entre alusão e eco - embora analisando menos passagens do Antigo Testamento. Este artigo propóe dar um passo além, ao analisar como essas alusões e ecos estão inseridas na disposição da carta segundo a Análise Retórica Bíblica Semítica. Os comentadores paulinos têm indicado, cada vez mais, que em Paulo a retórica e a teologia caminham juntas. Aliás, nas cartas paulinas, a retórica, de fato, náo é apenas uma moldura, mas um grande instrumento para se transmitir a mensagem do ressuscitado. Segundo Meynet, a contribuição da Análise Retórica Bíblica Semítica permite ver como o paralelismo dos membros, o quiasmo e os diversos níveis de um texto bíblico têm sua função na estruturação e mensagem do texto. Isso se torna mais eficiente quando se procura analisar a presença de citaçóes, alusóes e ecos do Antigo Testamento no Novo Testamento, a partir do método do Uso do Antigo Testamento no Novo Testamento integrado com a Análise Retórica Bíblica Semítica, como aqui em Colossenses. São duas metodologias distintas, mas que podem colaborar muito nas investigaçóes bíblicas para demonstrar que a ausência de citaçôes do Antigo Testamento nesta carta foi um recurso retórico utilizado por Paulo para oferecer ao leitor um magnífico texto capaz de unir cristologia, eclesiologia e a presença do Antigo Testamento, ainda que por meio de alusōes e ecos, e náo de citações explícitas.

*Articulo de investigaçáo

${ }^{a}$ Autor de correspondencia. Correio eletrônico: waldecir@hotmail.com 
Palavras-Chave: Colossenses; Antigo Testamento; Novo Testamento; Análise Retórica Bíblica Semítica; Beale; Foster; Beetham; citaçóes; alusôes; ecos.

\section{The Rhetorical Use of the Old Testament in the Letter to the Colossians}

Aвstract: The Letter to the Colossians, beyond the question if in fact is deutero-pauline or not, did enter in the middle of the discuss about the Methodology of the New Testament Use of the Old Testament. If during many years it was considered one of the few letters of the corpus paulinum that do not have any quotation from the Old Testament, Beale achieved to find many allusions. Foster critiqued the methodology used in Colossians, which deserved an answer by Beale. However, Beetham confirmed the use detected by Beale, specifying the differentiation between allusion and echo - though analyzing fewer passages from the Old Testament. This article proposes to take one-step beyond, by analyzing how these allusions and echoes are inserted in the letter's arrangement in according to the Semitic Biblical Rhetoric Analysis. Pauline commentators have increasingly indicated that in Paul rhetoric and theology go together. In fact, in the Pauline letters, rhetoric, indeed, is not just a frame, but a great instrument for transmitting the message of the Risen. According to Meynet, the contribution of Biblical Semitic Rhetorical Analysis allows us to see how the parallelism of the members, the chiasmus and the different levels of a biblical text have their role in the structuring and message of the text. This becomes more efficient when looking to analyze the presence of Old Testament quotes, allusions and echoes in the Novo Testamento, using the method of the Old Testament Use in the New Testament integrated with the Semitic Biblical Rhetorical Analysis, as here in Colossians. They are two distinct methodologies, but they can collaborate a lot in biblical investigations to demonstrate that the absence of Old Testament quotes in this letter was a rhetorical resource used by Paul to offer the reader a magnificent text capable of bringing together Christology, Ecclesiology and the presence of the Old Testament, albeit by means of allusions and echoes, and not by explicit quotations.

KeY Words: Colossians; Old Testament; New Testament; Semitic Biblical Rhetoric Analysis; Beale; Foster; Beetham; Quotes; Allusions; Echoes.

\section{COMO CITAR:}

Gonzaga, Waldecir, y Doaldo Ferreira Belem. "O Uso Retórico do Antigo Testamento na Carta aos Colossenses". Theologica Xaveriana (2021): 1-35. https://doi.org/10.11144/ javeriana.tx71.uratcc 


\section{Introdução}

Paulo é o "primeiro teólogo" do cristianismo, que "soube moldar seu ensino em forma de carta", um "missionário que se torna também escritor". E, embora desde a Antiguidade trabalhou-se com as citaçóes do Antigo Testamento feitas pelo Novo Testamento, apenas recentemente iniciou-se uma pesquisa sobre as alusóes e paralelos, tendo justamente no campo do corpus paulinum o trabalho pioneiro de Richard Hays ${ }^{2}$. Desde então, deflagrou-se um processo que Beetham denomina "paralelomania"3. A falta de um critério mais preciso - quando há alusão, e quando eco? - gerou críticas por parte de alguns estudiosos, na qual a Carta aos Colossenses ocupou um papel importante recentemente, justamente por não conter nenhuma citação do Antigo Testamento.

Outra coisa é a existência de livros do Antigo Testamento que não são citados no Novo Testamento e há vários, seja da Hebraica seja da LXX', mas este não é o objeto de nossos estudos. Porém, dos livros do Antigo Testamento citados no Novo Testamento, podemos computar ao redor de 300 citaçóes diretas e mais de 4.000 alusóes 5 , e em 90 \% dos casos das citaçôes a fonte usada foi a partir da versão grega da LXX e não do texto hebraico. Ademais, é importante também frisar que não há unanimidade entre os pesquisadores quando procuram distinguir entre citaçôes e alusóes ou entre alusóes e ecos .

Este artigo visa, portanto, debater o uso do Antigo Testamento nesta carta “apaixonante", seja ela do próprio Paulo ou da escola que deu continuidade à sua tradição, como defende a maioria dos autores. Para tanto, oferece-se um resumo da metodologia do uso do Antigo pelo Novo Testamento, proposta a partir de Richard Hays, passando pela "maturação" de Gregory Beale e sua "precisão" em Cristopher Beetham. Segue-se uma visão panorâmica da Carta aos Colossenses, com sua ênfase na questão - resumida - acerca da autoria, teologia e estrutura. Passa-se então à análise de como esta carta utiliza o Antigo Testamento, com foco nos trabalhos recentes específicos de Gordon Fee, Gregory Beale, Cristopher Beetham e Jerry Sumney.

O trabalho encerra-se com a contribuição da Análise Retórica Bíblica Semítica, o método sincrônico ao mesmo tempo "antigo" e "tornado recente" pelo estudioso

\footnotetext{
${ }^{1}$ Gonzaga, "O Corpus Paulinum no Cânon do Novo Testamento", 23.

${ }^{2}$ Hays, Echoes of Scripture in the Letters of Paul.

${ }^{3}$ Beetham, Echoes of Scripture in the Letter of Paul to the Colossians, 2-5.

${ }^{4}$ Proença, "O Uso do Antigo Testamento pelo Novo Testamento", 85.

${ }^{5}$ Ibid., 85-86.

${ }^{6}$ Silva, "Antigo Testamento em Paulo", 76.
} 
francês Roland Meynet ${ }^{7}$ que permite ver como o paralelismo, bem como os diversos níveis de perícopes, sequências e seções (níveis superiores retóricos) têm a sua função na estruturação e mensagem do inteiro texto da carta ${ }^{8}$, e principalmente como o uso do Antigo Testamento integra-se dentro da Análise Retórica Bíblica Semítica. Além disso, como afirma Aletti, é preciso que tenhamos em mente que em Paulo "retórica e teologia são inseparáveis", ao ponto de que "a sua maneira de usar a retórica manifesta não somente a qualidade de sua teologia, mas ainda sua concepção da teologia”.

\section{O uso do Antigo Testamento no Novo Testamento: metodologia}

Em razão das divergências verbais encontradas nas citaçóes paulinas do Antigo Testamento, Richard Hays propóe as seguintes perguntas: que tipo de texto era conhecido e usado por Paulo? Que livros e passagens do Antigo Testamento são citados por Paulo? Que tipo de tradição interpretativa Paulo representa? Paulo modifica ou não o sentido original da citação? 10

No que diz respeito ao texto do Antigo Testamento utilizado dentro do Novo Testamento, raramente as citaçôes - especialmente as paulinas - são retiradas do texto hebraico ao invés da Septuaginta ${ }^{11}$; e, quando isso ocorre, pode ser explicado como uma variante textual da Septuaginta submetida à uma "revisão hebraizante", uma tendência atestada nas versôes gregas de Áquila, Símaco e Teodocião ${ }^{12}$. Além das citações, Hays propóe uma discussão com base no fenômeno da intertextualidade ${ }^{13}$ partindo do

${ }^{7}$ Meynet, Trattato di Retorica Bíblica, 132-209; Meynet, L'Analise Retorica, 159-249. Nestas duas obras, Meynet explica o Método da Análise Retórica Bíblica Semítica, fazendo uma exposição sobre os niveis de composição de um texto e os frutos da aplicação do método em cada um dos níveis de um texto ou livro bíblico: 1. Niveis ou figuras de composição de um texto: (1.1) membro (1.2) segmento; (1.3) trecho; (1.4) parte; (1.5) perícope ou passagem; (1.6) sequência; (1.7) seção; 8) livro. 2. Frutos da aplicação da Análise Retórica: (2.1) delimitar as unidades literárias e textuais; (2.2) auxiliar na interpretação; (2.3) ler junto as diversas pericopes; (2.4) auxiliar na tradução do texto; (2.5) ajudar na critica textus; (2.6) fornecer procedimentos e critérios científicos - de tipo linguístico - para a delimitação das unidades literárias aos diversos níveis da organização do texto.

${ }^{8}$ Gonzaga, "O Salmo 150 à luz da Análise Retórica Bíblica Semítica”, 159-160.

${ }^{9}$ Aletti, “Uma retórica paulina: construção e comunicação de um pensamento”, 51.

${ }^{10}$ Hays, Echoes of Scripture in the Letters of Paul, 6-9.

${ }^{11}$ Rahlfs e Hanhart (eds.), Septuaginta.

${ }^{12}$ Hays, Echoes of Scripture in the Letters of Paul, xi.

${ }^{13}$ Segundo Frank, em sua obra Der Kolosserbrief im Kontext des paulinischen Erbes: eine intertextuelle Studie zur Auslegung und Fortschreibung der Paulustradition, 327-369, a Carta aos Colossenses, tomada como o mais antigo dos textos pseudoepígrafos paulinos, também chamados de deuteropaulinos, é um testemunho bíblico estruturado essencialmente de forma intertextual, onde ele examina as estratégias 
trabalho de pesquisa literária efetuada por John Hollander, onde a continuidade dentro da tradição equipara-se a "poetas que honram as vozes dos mortos mesmo quando formam ecos que transformam suas palavras em um novo ambiente acústico" ${ }^{14}$.

Vários são os autores que tratam da temática do uso do Antigo Testamento no Novo Testamento, como um todo, como é o caso de Beale, ou no uso do Antigo Testamento em Paulo, como é o caso de Hays. Usaremos estas duas obras visto que no dão os critérios e passos a serem trilhados a fim de se encontrar e distinguir as citaçôes, alusôes e ecos do Antigo Testamento no Novo Testamento, ainda que com todos os seus limites, pois vale a pena sempre recordar que não é tarefa tão fácil estabelecer os limites entre alusóes ou ecos, pois são muito próximas e implícitas, e não explícitas como as citaçôes.

Hays então define um "eco alusivo": quando o texto B pode ser compreendido à luz de uma ampla interação com o texto $\mathrm{A}$, abrangendo aspectos do texto A que ultrapassam aqueles explicitamente ecoados. E, após análise de uma passagem da Carta aos Filipenses, especifica a diferenciação entre citação, alusão e eco como "ecos intertextuais" que variam de acordo em volume, movendo-se do explícito para o subliminar: quanto mais nos distanciamos da citação aberta, mais as relaçôes intertextuais tornam-se menos determinadas. Concentrando-se nos ecos "de alto volume", cujo caráter alusivo torna-se prontamente audível ${ }^{15}$, fornece sete testes para detecção dos ecos:

1. Disponibilidade: a suposta fonte para o eco está à disposição do autor e dos leitores? Se sim, foi a partir do texto hebraico ou grego?

2. Volume: qual o grau de repetiçáo de palavras ou padróes sintáticos no texto precursor e no eco neotestamentário?

3. Recorrência: quantas vezes o autor faz referências ao texto aludido ou ao contexto veterotestamentário usado?

e mecanismos intertextuais que são eficazes, enquanto meios literários, para a transmissão da teologia paulina. Nesta carta, segundo este autor, o recurso ao conteúdo, à linguagem e aos demais dados que encontramos nas cartas autenticamente paulinas, por ele chamadas de protopaulinas, como a própria teologia paulina, constitui um pré-requisito a partir do qual o autor da mesma possa ter acesso e a transmitir a autêntica tradição paulina, que, por sua vez, está sempre sujeita a uma reinterpretaçáo, onde ele elabora e transmite a herança paulina. Neste sentido, Frank defende que a Carta aos Colossenses, embora não sendo autenticamente paulina, está mergulhada no contexto da herança paulina, bebe da intertextualidade das cartas protopaulinas e, mais ainda, ela leva adiante a tradição paulina.

${ }^{14}$ Hays, Echoes of Scripture in the Letters of Paul., 15-19.

${ }^{15}$ Ibid., 20-24. 
4. Coerência temática: até que ponto o suposto eco se adapta à linha argumentativa desenvolvida pelo autor do Novo Testamento?

5. Plausibilidade histórica: até que ponto é plausível a afirmação de que o autor do Novo Testamento usou o eco para conseguir um determinado efeito de sentido ressonante nos leitores da época?

6. História da interpretação: outros autores e leitores foram capazes de perceber os mesmos ecos que teriam percebido os contemporâneos do escrito?

7. Satisfação: faz sentido a sua utilização em seu contexto imediato, esclarece e aumenta o vigor retórico da argumentação? ${ }^{16}$

Beale elabora então posteriormente um "Manual do Uso do Antigo Testamento no Novo Testamento", analisando a possibilidade de um "livro-testemunho", uma compilação de "textos-prova" para fins apologéticos, possíveis fontes para as referências ao Antigo Testamento feitas pelos escritores do Novo Testamento ${ }^{17}$. Volta-se então para o uso mais amplamente detectado no Novo Testamento, o tipológico, fornecendo cinco critérios para identificação do mesmo:

1. Estreita correspondência analógica de verdades sobre pessoas, fatos ou instituiçóes

2. Historicidade

3. Apontar para o futuro

4. Intensificação de sentido entre as correspondências

5. Retrospecção ${ }^{18}$

Após essas considerações introdutórias, Beale define uma citação como "reproduçáo direta de uma passagem do Antigo Testamento facilmente identificável por seu paralelismo vocabular claro e bem característico" ", e a alusão como "uma expressáo breve deliberadamente pretendida pelo autor para ser dependente de uma passagem do Antigo Testamento" ${ }^{20}$ - uma citação, pois, é uma referência direta, enquanto a alusão é indireta. E, entendendo que a diferenciação entre eco e alusão é de "pouca utilidade" ${ }^{21}$, não estabelece nenhum critério para tal diferenciação. Somente então Beale aponta nove passos para interpretar o uso do Antigo Testamento no Novo:

\footnotetext{
${ }^{16}$ Ibid., 29-32.

${ }^{17}$ Beale, Manual do uso do Antigo Testamento no Novo Testamento. Exegese e interpretação, 27.

${ }^{18}$ Ibid., 42.

${ }^{19}$ Ibid., 53.

${ }^{20}$ Ibid., 55.

${ }^{21}$ Ibid., 56.
} 
1. Identificar e validar se há uma citação, alusão ou eco (neste primeiro passo são retomados os sete critérios propostos por Hays).

2. Analisar o contexto geral do Novo Testamento em que ocorre a referência ao Antigo Testamento.

3. Analisar o contexto imediato e o contexto geral do Antigo Testamento, interpretando atenta e minuciosamente sobretudo o parágrafo em que a citação, alusão ou eco ocorre.

4. Pesquisar quanto ao uso do texto do Antigo Testamento no judaísmo anterior e posterior, o que possa ser importante para a apropriação do texto veterotestamentário pelo Novo Testamento.

5. Comparar os textos, inclusive suas variantes textuais: Novo Testamento, Septuaginta, Texto Massorético e os Targumim, citaçóes judaicas antigas (Manuscritos do Mar Morto, Pseudepígrafos, Flávio Josefo, Filon de Alexandria).

6. Analisar o uso textual que o autor faz do Antigo Testamento, para se ver em qual tradiçấo textual veterotestamentária o autor se apoia, ou se ele está dando sua versão pessoal, e como isso afeta a interpretação do texto do Antigo Testamento.

7. Analisar o uso interpretativo, hermenêutico, que o autor faz do Antigo Testamento.

8. Analisar o uso teológico que o autor faz do Antigo Testamento.

9. Analisar o uso retórico que o autor faz do Antigo Testamento ${ }^{22}$.

Beetham, então, não somente incorporou os passos já apontados por Hays e por Beale (este, seu orientador na tese doutoral), como aprimorou a identificaçâo entre citação, alusão e eco.

- A citação deve ser intencional, explícita, verbatim ou quase de um texto anterior, contendo seis ou mais palavras deste, sendo formal quando acompanhada de fórmula introdutória ou informal na falta dessa ${ }^{23}$.

- Uma alusão constitui um recurso literário intencionalmente empregado pelo autor, direcionando os leitores a uma única fonte identificável, ou no qual um ou mais componentes são trazidos a um novo contexto a fim de que o texto aludido possa ser plenamente compreendido. Uma alusáo é menos explícita do que uma citação, e mantém o "limite linear" de cinco palavra ou menos - a

${ }^{22}$ Beale, Manual do uso do Antigo Testamento no Novo Testamento. Exegese e interpretação, 68-69.

${ }^{23}$ Beetham, Echoes of Scripture in the Letter of Paul to the Colossians, 15-17. 
não ser que seja precedida de uma "fórmula introdutória", constituindo então uma citação e não uma alusão ${ }^{24}$.

- Um eco define-se como um modo de referência literário sutil sem pretensóes de reconhecimento pelo público, ainda que derive de um predecessor (fonte) específico. Um autor pode ecoar um predecessor consciente ou inconscientemente, contextualmente ou não - um eco, portanto, é menos explicito do que uma alusão ${ }^{25}$.

Beetham ainda acrescenta o conceito de paralelismo: um modo não literário de referência, quando não existem evidências fortes o suficiente para afirmar que texto $x$ deriva de $y$, mas que apontam para tradiçóes compartilhadas na comunidade identificadas por dados fornecidos pelas Escrituras como um todo ${ }^{26}$.

\section{Carta aos Colossenses: Visão Panorâmica}

\section{Autoria}

A Carta aos Colossenses vem sendo intensamente debatida pela sua autoria: antigamente reputada como paulina, hoje um grupo de acadêmicos - conforme citado por Beetham, cerca de $60 \%$ - a qualifica como uma das três deuteropaulinas, ao lado de Efésios e 2Tessalonicenses ${ }^{27}$.

A primeira negaçáo da autoria paulina de Colossenses em tempos modernos data de 1838 quando E. T. Mayerhoff afirmou ter encontrado na carta pensamentos não-paulinos, evidências de disputas com Cerinto e uma dependência de Efésios, e que a heresia combatida na carta seria um gnosticismo do segundo século ${ }^{28}$. Schweizer aponta que "existe uma clara afinidade entre a carta aos Colossenses e a carta aos Efésios” ${ }^{29}$; opinião esta que é compartilhada pela maioria, como nos indica Aletti ${ }^{30}$.

Mas, na Antiguidade, nunca teve sua autoria posta em dúvida, aparecendo em todos os catálogos canônicos, incluindo os cânones de Marciáo e o Muratoriano

\footnotetext{
${ }^{24}$ Ibid., 17-20.

${ }^{25}$ Ibid., 20-24.

${ }^{26}$ Beetham, Echoes of Scripture in the Letter of Paul to the Colossians, 24; cf. também Sumney, "Writing 'In the Image' of Scripture: The Form and Function of References to Scripture in Colossians", 216-217.

${ }^{27}$ Beetham, Echoes of Scripture in the Letter of Paul to the Colossians, 23.

${ }^{28}$ O’Brien, Colossians, Philemon, xli.

${ }^{29}$ Schweizer, La Carta a los Colosenses, 22.

${ }^{30}$ Aletti, Lettera ai Colessesi, 26.
} 
- embora em diferentes posições na ordem, o que indicaria diferentes avaliaçóes acerca de seu grau de importância ${ }^{31}$.

Beale $^{32}$ e Beetham ${ }^{33}$ partem do princípio de que se trata de uma carta "autenticamente" paulina. O’Brien defende vigorosamente a autoria paulina, declarando que "a carta deixa claro que o autor é o apóstolo Paulo" ${ }_{34}$. Pérez Millos declara que se pode descobrir "com toda clareza" que o autor da carta é Paulo ${ }^{35}$. James Dunn usa uma solução "conciliatória": os inúmeros pontos de contato com a teologia paulina pressupóe uma carta encomendada por Paulo a Timóteo quando aquele ainda se encontrava na prisão. Isto faria desta carta um escrito de "fronteira", sendo o primeiro escrito da escola paulina quando Paulo ainda estaria vivo ${ }^{36}$. Pao analisa que, dentre as diversas possibilidades, considerar Paulo como o autor da carta ainda é a "melhor hipótese" ${ }^{37}$.

Mas Boring faz uma longa análise dos argumentos favoráveis a uma identificação não-paulina: Colossenses possui 86 palavras não encontradas nas cartas indisputadas: 34 são hápax legomena, 28 são encontradas em outras passagens do Novo Testamento, mas não nas cartas indisputadas; outras 25 são encontradas apenas em Colossenses e Efésios. Importantes vocábulos que são especificamente paulinos estáo ausentes em

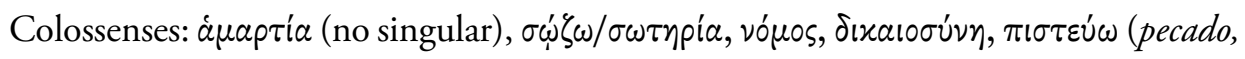
salvação, lei, justificação, crer). Em contraste com o vívido estilo de Paulo, sentenças vão e voltam, frouxamente unidas por conjunçóes e pronomes relativos. Outro elemento característico é usar expressóes com mais de uma palavra proveniente do

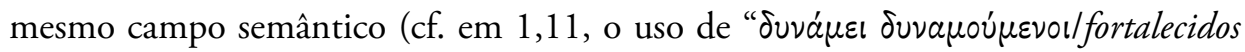
em força") $)^{38}$.

Com tudo isso, Boring conclui que a Carta aos Colossenses parece ter sido composta por alguém que cuidadosamente estudou a coleção das cartas paulinas, e foi influenciado pelo vocabulário destas - por um autor da escola paulina que adotou,

\footnotetext{
${ }^{31}$ Gonzaga, Compêndio do Cânon Bíblico. Listas dos Catálogos Bíblicos: Antigo Testamento, Novo Testamento e Apócrifos, 406-407.

${ }^{32}$ Beale, "Colossenses", 1039.

${ }^{33}$ Beetham, Echoes of Scripture in the Letter of Paul to the Colossians, 9.

${ }^{34}$ O'Brien, Carta aos Colossenses, 251.

${ }^{35}$ Pérez Millos, Comentario exegético al texto griego del Nuevo Testamento. Colosenses, 217.

${ }^{36}$ Dunn, The Epistles to the Colossians and to Philemon. A Commentary on the Greek Text, 18; 38.

${ }^{37}$ Pao, Colossians and Philemon, 23.

${ }^{38}$ Boring, Introdução ao Novo Testamento. História, literatura e teologia. Vol. 1. Questōes introductórias do Novo Testamento e escritos paulinos, 558-560
} 
adaptou, e elaborou material de Filemon. Seu autor seria um paulinista para as igrejas paulinas na Ásia Menor, possivelmente redigida em Éfeso por volta de 70 ou 80 d. C. ${ }^{39}$.

Além de Boring, temos muitos outros autores que igualmente consideram que a carta aos Colossenses não é de escrita autenticamente e genuinamente paulina. Em especial, a crítica alemã, do século XIX levantou problemas em relação à questão "lexicográfica, estilo e teologia", bem como sobre a própria "construção das frases da carta” ${ }^{\prime 4}$, demonstrando outra mão na redação deste texto que muitos consideram como uma das três cartas deuteropaulinas ${ }^{41}$.

\section{Teologia}

Uma análise acurada da teologia presente na Carta aos Colossenses fornece mais argumentos em prol de uma autoria não-paulina: enquanto as cartas indisputadas se referem mais de 90 vezes ao Espírito Santo, em Colossenses temos apenas duas alusões, e mesmo assim possivelmente ao espírito humano $(1,8 ; 2,5)$. Aqui, ser cristão é viver na esfera de Cristo $(1,11)$, mas isso não é expresso (como em Paulo) em termos do Espírito Santo. Cristologia e eclesiologia estão intimamente entrelaçados, mas de maneira diferente da abordagem paulina: enquanto para Paulo o crente já está crucificado com Cristo, mas ainda não ressuscitado com ele, Colossenses apresenta a vida do crente já unida à de Cristo de tal forma que aquele já está ressuscitado com este $(3,1-4)^{42}$; e a expectativa da proximidade da parusia desaparece completamente. Se Paulo sempre usa "igreja" para se referir primariamente à comunidade local, em Colossenses a Igreja é identificada com o corpo cósmico de Cristo, do qual o próprio Cristo é o cabeça (ao contrário da concepçáo paulina de Cristo como a totalidade do corpo ${ }^{43}$.

Mas é a chamada "heresia colossense" que tem recebido grandes debates dos estudiosos. Esta seria propagada por um grupo de vigorosos mestres procurando subverter o evangelho para ativamente levar os cristãos a um sistema diferente de féét. Sugere-se que a "heresia colossense" seria um desenvolvimento frígio no qual uma

\footnotetext{
${ }^{39}$ Ibid., 555-557; 565.

${ }^{40}$ Aletti, Lettera ai Colessesi, 24. Para maiores detalhes sobre as pesquisas referentes à Carta aos Colossenses, ainda que não tão atual, pois foi publicada em 1987 e traz os dados das pesquisas entre 1945-1985, mas com bom status quaestionis sobre a temática, indicamos o ensaio de Schenk, "Der Kolosserbrief in der neueren Forschung (1945-1985)”, 3327-3365.

${ }^{41}$ Gonzaga, "O Corpus Paulinum no Cânon do Novo Testamento", 22.

${ }^{42}$ Schweizer, La Carta a los Colosenses, 148.

${ }^{43}$ Boring, Introdução ao Novo Testamento. História, literatura e teologia. Vol. 1. Questóes introductórias do Novo Testamento e escritos paulinos, 563-564.

${ }^{44}$ Dunn, The Epistles to the Colossians and to Philemon. A Commentary on the Greek Text, 25.
} 
variante local de judaísmo teria sido fundida com uma filosofia de origem não-judaica - uma forma simples de gnosticismo sincretista ${ }^{45}$.

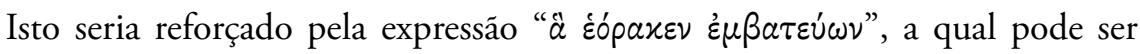
traduzida como "entrado no que tem visto", e refletiria práticas típicas das religiōes de mistério ${ }^{46}$. Mas as descobertas de Qumran evidenciaram pontos de contato com a

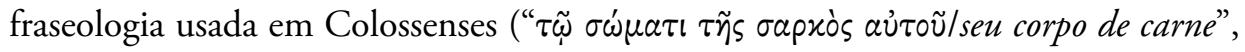
cf. Cl 1,22; 2,11 e 1QpHab 9,1.2), levando alguns a considerarem a "filosofia colossense" como uma variante do ensinamento da comunidade de Qumran. Entretanto, não encontramos nenhuma referência a uma insistência em cerimoniais de ablução, os quais exerceram papel significante entre os essênios em geral e na comunidade de Qumran em particular - o batismo não é contraposto a estes cerimoniais, e sim à circuncisão (cf. Cl 2,11-12) 47 $^{4}$.

Não obstante, com as descobertas dos manuscritos do Mar Morto, o "pêndulo" virou de uma proposta de gnosticismo sincretista em direção a um ensinamento distintamente judaico. Faz mais sentido em razão das implicações de passagens como 1,12.21-22; 2,13 e 3,11-12 com seu foco nos privilégios pactuais judaicos, tornando desnecessária a hipótese do sincretismo gnosticista, e como imaginação histórica o "judaísmo gnóstico" ${ }^{48}$. A sugestão de que 2,18 refere-se à visão de anjos durante ritos de mistério no culto colossense ${ }^{49}$ pode então ser abandonada desde que o versículo seja mais plausivelmente interpretado como adentrando-se no templo celestial para adorar junto com os anjos, ao invés de um culto aos anjos ${ }^{50}$.

\section{Estrutura}

A Carta aos Colossenses é dividida em duas seçóes, que seguem o padrão generalizado das cartas paulinas: uma doutrinária $(1,3-3,4)$ e outra parenética $(3,5-4,6)$, emolduradas por uma saudação inicial $(1,1-2)$ e outra final $(4,7-18)^{51}$. Após a oração

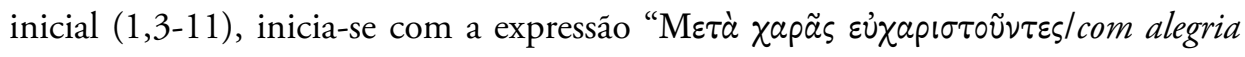
dando graças", em 1,12 (segundo a divisão dos versículos proposta pela Novum

${ }^{45}$ Ibid., 27; O’Brien, Colossians, Philemon, xxxiii.

${ }^{46}$ Barth, Blanke e Beck, Colossians. A New Translation with Introduction and Commentary, 33-34.

${ }^{47}$ O’Brien, Colossians, Philemon, xxxiv.

${ }^{48}$ Dunn, The Epistles to the Colossians and to Philemon. A Commentary on the Greek Text, 29; 33-34.

${ }^{49}$ Lohse, Colossians and Philemon, 120.

${ }^{50}$ Dunn, The Epistles to the Colossians and to Philemon. A Commentary on the Greek Text, 28.

${ }^{51}$ Beale, "Colossenses", 1072. 
Testamentum Graece, ed. 2852, que desloca $\mu \varepsilon \tau \dot{\alpha}$ do versículo anterior) uma nova

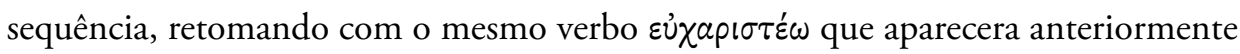
no v. 3, agora enfatizando a obra divina mediante Cristo. Esta sequência é composta pelo hino cristológico $(1,15-20)$, emoldurado pela obra da redenção $(1,12-14)$ e da reconciliação $(1,21-23)$.

Em 1,24 a terceira pessoa do singular muda para a primeira pessoa do singular, onde o apóstolo narra o que tem feito pelos colossenses: anunciar o mistério para o corpo que é a Igreja (1,24-29), e reiterar sua luta pelos laodicenses e pelos colossenses $(2,1-5)$. Em 2,6 volta a ênfase na terceira pessoa do plural, para advertir sobre um perigo: o engano de outros, não identificados, que procuram enredar os colossenses com "vãs e enganosas filosofias" (cf. 2,8). Mas, antes de esmiuçar essa "filosofia" em 2,16-19, enfatiza-se a "circuncisão não feita por mãos", a "nova circuncisão" (2,6-15) que se contrapõe então à "velha circuncisão".

Segue-se uma conclusão da parte doutrinária: se morrestes com Cristo, por que ainda sujeição a velhas ordenanças? (2,20-23) A expressão "Eỉ oũv/portanto, se...", em 3,1 , conclui, não somente a falácia da "heresia colossense", mas toda a seção doutrinária. Em 3,5 começa a seção parenética, abordando tudo que os cristáos precisam praticar: uma série de admoestaçôes do que deve ser evitado, iniciando com "mortificai" (3,5-11); uma série de virtudes que devem ser cultivadas, iniciando com "revestivos" (3,12-17); uma série de deveres domésticos $(3,18$ - 4,1); e, finalizando, uma exortação final da parte do apóstolo (4,2-6), complementando e concluindo toda essa seção parenética. Desta forma, numa análise preliminar, chega-se à seguinte estrutura:

I Saudação inicial $(1,1-2)$

II Seção doutrinária $(1,3-3,4)$

1. Oração inicial (1,3-11)
(a) Ação de graças (1,3-8)
(b) Intercessão (1,9-11)

2. Obra de Cristo $(1,12-23)$

(a) Redenção (1,12-14)

(b) Hino cristológico $(1,15-20)$

(c) Reconciliação (1,21-23)

3. Obra apostólica $(1,24-2,5)$

\footnotetext{
${ }^{52}$ Nestle-Aland, Novum Testamentum Graece (ed. 28).
} 
(a) O anúncio do mistério (1,24-29)

(b) A luta pelos colossenses (2,1-5)

4. A "Heresia colossense" (2,6-19)

(a) A "Nova circuncisão" (2,6-15)

(b) A "Velha circuncisão" (2,16-19)

5. Conclusão doutrinária $(2,20-3,4)$

(a) Sujeição a velhas ordenanças $(2,20-23)$

(b) Ressuscitados com Cristo (3,1-4)

III Seção parenética $(3,5-4,1)$

1. A "nova vida" em Cristo $(3,5-4,1)$

(a) Mortificar a natureza terrena (3,5-11)

(b) Revestimento do cristão (3,12-17)

(c) Deveres familiares $(3,18-4,1)$

2. Exortação final (4,2-6)

IV Saudação final (4,7-18)

1. Notícias sobre Paulo (4,7-9)

2. Saudações (4,10-18)

\section{Uso do Antigo Testamento na Carta aos Colossenses}

\section{Estado da pesquisa}

Se os diversos estudiosos concordam que de fato não existe nenhuma citação do Antigo Testamento na Carta aos Colossenses ${ }^{53}$, há influência e presença forte o suficiente daquele nesta, algo já observado por Henry Gough em 1855 segundo Beetham

\footnotetext{
${ }^{53}$ Quando tomamos uma Bíblia de Jerusalém em mãos e percorremos os olhos pelas notas de fontes do uso do Antigo Testamento e de paralelos do Novo Testamento na Carta aos Colossenses, é interessante observar que a equipe de biblistas que trabalhou na tradução da mesma, ao colocar possíveis textos usados como fontes, cita alguns textos do Antigo Testamento, reconhecendo assim a possiblidade de pelo menos alusōes indiretas às fontes veterotestamentárias, nas seguintes relações: $\mathrm{Sb}$ 7,26 em Cl 1,15-20; $\operatorname{Pr} 8,22$ em Cl 1,18; Is 45,3 e Pr 2,4-5 em Cl 2,3; Jr 4,4 em Cl 2,11; Is 29,13 em Cl 2,22; Sl 110,1 em $\mathrm{Cl}$ 3,1; Gn 1,26-27; 11,1 em Cl 3,9; e Sb 8,9 em Cl 4,5-6. A Biblia TEB, por sua vez, reconhece menos relações entre o Antigo Testamento e a Carta aos Colossenses que a Bíblia de Jerusalém. Enquanto a Bíblia de Jerusalém reconhece todas as acima mencionadas, a $A$ Bíblia TEB reconhece apenas as seguintes: Is 45,3; Pr 2,2 em Cl 2,3; Is 229,13 (LXX) em Cl 2,22; e Sl 110,1 em Cl 3,1.
} 
- e este então sumariza o status quaestionis desde meados do século XIX até o final do século $X^{54}$. Embora o primeiro trabalho moderno dedicado exclusivamente a Colossenses tenha sido publicado em 2006 por Gordon Fee ${ }^{55}$, o pioneirismo coube a Beetham na sua tese doutoral em 2005. A orientação coube a Beale, que publicou também uma extensa análise em seu "Comentário do Uso do Antigo Testamento no Novo Testamento", em 2007. Finalmente Beetham publicou sua tese como livro em 200856. Sumney publica entáo um artigo em 2012, no qual acrescenta paralelos, além da análise dos ecos e alusóes encontrados nos demais autores e outros por ele detectados; embora reconheça como Beetham a diferença entre alusáo e eco, prefere não especificar para as passagens listadas ${ }^{57}$.

Outros autores modernos não se detiveram numa análise minuciosa: Robertson apenas comenta brevemente as alusóes de Is 29,13 em Cl 2,18-23 e do Sl 110,1 em $\mathrm{Cl} 3,1^{58}$; segundo Kalvesmaki Is 29,13 é aludido em Cl 2,2 e o $\mathrm{Sl} 110,1$ em Cl 3,159, e Belli não reconhece que haja alusôes que remetam de algum modo a um texto da Escritura, embora debata a possibilidade de uma mençáo ao mistério de Dn 2 como possível explicação a este tipo de ausência ${ }^{60}$. Foster entâo avaliou como "exagero" a identificação nesta carta de inúmeras alusóes e/ou ecos ao Antigo Testamento por parte de três estudiosos: Gordon Fee, Beale e Beetham.

Neste sentido, Foster criticou a falta de uniformidade na quantidade de alusóes e/ou ecos identificados - 10 ecos por Gordon Fee e 17 alusóes por Beale, enquanto Beetham identifica 2 alusôes e $9 \operatorname{ecos}^{61}$. Houve então a necessidade de uma resposta de Beale, defendendo o método: analisar o uso do Antigo Testamento em Colossenses não somente é possível como importante para compreender seu argumento e teologia; os três estudiosos utilizam diferentes metodologias, as quais são ignoradas por Foster; há apenas diferenças quantitativas de alusôes e/ou ecos identificados, e não qualitativas,

\footnotetext{
${ }^{54}$ Beetham, Echoes of Scripture in the Letter of Paul to the Colossians, 3-6.

${ }^{55}$ Fee, "Old Testament Intertextuality in Colossians: Reflections on Pauline Christology and Gentile Inclusion in God's Story”, 201-221.

${ }^{56}$ Beale, "Colossenses", 1039.

${ }^{57}$ Sumney, "Writing 'In the Image' of Scripture: The Form and Function of References to Scripture in Colossians", 185-229.

${ }^{58}$ Robertson, El Antiguo Testamento en el Nuevo, 175.

${ }^{59}$ Kalvesmaki, Old Testament Quotations in the New Testament, 54.

${ }^{60}$ Belli, Carbajosa, Jódar Estrella, Sánchez Navarro, Vetus in Novo. El recurso a la escritura en el Nuevo Testamento, 202-203.

${ }^{61}$ Foster, "Critiquing Certain Aspects of Recent Scholarly Trends in the Study of the Jewish Scriptures in the New Testament", 104-107.
} 
com mais sobreposiçóes do que diferenças; as diferentes alternativas interpretativas propostas para uma mesma passagem não invalidam o método; e, se os comentaristas discordam sobre quais alusões e/ou ecos podem ser identificados em Colossenses, isto não nega a presença de linguagem alusiva na epístola. E Beale ainda pontua que, uma vez que o artigo de Foster foi publicado em 2015, "lamentavelmente" omitiu o "substancial artigo" de Sumney".

Isto pode ser evidenciado pela tabela elaborada pelo próprio Foster, reproduzida aqui com adaptaçóes, como o acréscimo da abordagem de Sumney e a retirada das referências da Novum Testamentum Graece (ed. 28), pois sua lista de alusóes é apenas indicativa, não trazendo nenhuma nota explicativa ${ }^{63}$ :

\begin{tabular}{|c|c|c|c|c|c|}
\hline $\begin{array}{l}\text { PASSAGEM EM } \\
\text { COLOSSENSES }\end{array}$ & $\begin{array}{l}\text { INTERTEXTUAL } \\
\text { DO AT }\end{array}$ & FEE & BEALE & BEETHAM & SUMNEY \\
\hline $\mathrm{Cl} 1,5$ & $\begin{array}{l}\text { "Palavra da } \\
\text { Verdade" }\end{array}$ & & & & Paralelo \\
\hline $\mathrm{Cl} 1,6.10$ & Gn 1,28 & & Alusão & Eco & Alusão/eco \\
\hline $\mathrm{Cl} 1,9-10$ & $\begin{array}{l}\text { Ex 31,3; } \\
35,31-32 \text {; Is } \\
11,2\end{array}$ & $\begin{array}{l}\text { Eco } \\
(\text { Is } 11,2)\end{array}$ & Alusão & $\begin{array}{l}\text { Eco } \\
\text { (Is 11,2.9) }\end{array}$ & $\begin{array}{l}\text { Alusão/eco } \\
\text { (Is 11,2.9) }\end{array}$ \\
\hline $\mathrm{Cl} 1,12-14$ & $\begin{array}{l}\text { Motivo do } \\
\text { êxodo }\end{array}$ & Eco & Alusão & Eco & $\begin{array}{l}\text { Motivo do } \\
\text { êxodo }\end{array}$ \\
\hline $\mathrm{Cl} 1,13$ & $2 \mathrm{Sm} 7,12-16$ & $\begin{array}{l}\text { Eco } \\
(2 \mathrm{Sm} \\
7,14.18)\end{array}$ & Alusão & $\begin{array}{l}\text { Eco } \\
(2 \mathrm{Sm} 7,12-18)\end{array}$ & \\
\hline $\mathrm{Cl} 1,15$ & Gn $1,26-28$ & Eco & Alusão & & Alusão/eco \\
\hline
\end{tabular}

${ }^{62}$ Beale, "The Old Testament in Colossians: A Response to Paul Foster", 265-270. Para uma análise detalhada sobre a linguagem da Carta aos Colossenses, indicamos a obra Bujard, Stilanalytische Untersuchungen zum Kolosserbrief: als Beitrag zur Methodik von Sprachvergleichen, onde o autor apresenta um estudo e análise do estilo linguístico presente em Colossenses, realmente oferecendo uma grande contribuição à metodologia de comparação de idiomas. O autor demonstra que, embora a Carta aos Colossenses seja tida como deuteropaulina, ela contém numerosos exemplos de vocabulário e fraseologias típicos de cartas paulinas autênticas. Porém, o autor reforça que uma coisa que impressiona muito nesta carta é a diferença entre a linguagem de Paulo, em suas cartas autênticas, e a de Colossenses, inclusive com um alto número de hápax legomena.

${ }^{63}$ Foster, "Critiquing Certain Aspects of Recent Scholarly Trends in the Study of the Jewish Scriptures in the New Testament", 106. 


\begin{tabular}{|c|c|c|c|c|c|}
\hline $\mathrm{Cl} 1,15$ & $\begin{array}{l}\text { Sl 89,27 } \\
\text { [LXX 88,28] }\end{array}$ & Eco & Alusão & & $\begin{array}{l}\text { Alusão/eco } \\
(+ \text { Ex } 4 \\
22-23)\end{array}$ \\
\hline $\mathrm{Cl} 1,15-17$ & $\begin{array}{l}\text { Tema da } \\
\text { Sabedoria }\end{array}$ & & $\begin{array}{l}\text { Alusão } \\
\text { (possível) }\end{array}$ & & \\
\hline $\mathrm{Cl} 1,15-20$ & $\operatorname{Pr} 8,22-31$ & & & Alusão & Alusão/eco \\
\hline $\mathrm{Cl} 1,18$ & Gn 1,1 & Eco & & & \\
\hline $\mathrm{Cl} 1,19$ & $\begin{array}{l}\text { S1 68,17 } \\
{[\mathrm{LXX} 67,17]}\end{array}$ & & Alusão & Eco & $\begin{array}{r}\text { Alusão/eco } \\
(\mathrm{S} 168,16)\end{array}$ \\
\hline $\mathrm{Cl} 1,26-27$ & Dn 2 & & Alusão & & \\
\hline $\mathrm{Cl} 2,2-3$ & $\operatorname{Dn} 2 ; \operatorname{Pr} 2,3-6$ & & Alusão & & \\
\hline $\mathrm{Cl} 2,11$ & Dt 30,6 & & Alusão & Eco & Alusão/eco \\
\hline $\mathrm{Cl} 2,13$ & Gn $17,10-27$ & & Alusão & Eco & $\begin{array}{l}\text { Alusão/eco } \\
(+\mathrm{Ez} 44,7.9)\end{array}$ \\
\hline $\mathrm{Cl} 2,16$ & $\begin{array}{l}\text { Os 2,13 LXX } \\
\text { e Ez } 45,17\end{array}$ & & & & Alusão/Eco \\
\hline $\mathrm{Cl} 2,22$ & Is 29,13 & Eco & Alusão & Eco & Alusão/eco \\
\hline $\mathrm{Cl} 3,1$ & Sl 110,1 & Eco & Alusão & Eco & Alusão/eco \\
\hline $\mathrm{Cl} 3,9-10$ & Gn $1,26-28$ & Eco & $\begin{array}{l}\text { Alusão } \\
(+ \text { Gn 3,7-21) }\end{array}$ & Alusão & Alusão/eco \\
\hline $\mathrm{Cl} 3,12$ & Dt 7,6-8 & Eco & & & Alusão/eco \\
\hline $\mathrm{Cl} 3,17$ & $\begin{array}{l}\text { "Nome do } \\
\text { Senhor" }\end{array}$ & & & & Paralelo \\
\hline $\mathrm{Cl} 3,20$ & $\begin{array}{l}\text { Ex 20,12; } \\
\text { Dt } 5,16\end{array}$ & & & & Alusão/eco \\
\hline
\end{tabular}




\begin{tabular}{|l|l|l|l|l|l|}
\hline Cl 3,22 & Sl 52,6 LXX & & & & Paralelo \\
\hline Cl 4,5 & Dn 2,8 & & Alusão & & \\
\hline
\end{tabular}

A tabela proposta por Foster apresenta ainda uma inconsistência: lista como referência da Novum Testamentum Graece (ed. 28) em Cl 4,1 a Lv 25,43-53 e Ecl 5,7, as quais constam de fato na Novum Testamentum Graece (ed. 27) ${ }^{64} \mathrm{e}$ foram retiradas da edição posterior. A Novum Testamentum Graece (ed. 28) ainda reconhece (não incluindo os pseudepígrafos) uma alusão a Is $53,5 \mathrm{em} \mathrm{Cl} \mathrm{1,20;} \mathrm{a} \mathrm{Eclo} \mathrm{1,24-25;} \mathrm{Is} \mathrm{45,3;}$ Pr 2,3-4 em Cl 2,3; a Eclo 23,16 em Cl 2,11; e a Tb 10,13 em Cl 3,20. A Novum Testamentum Graece (ed. 28) confirma a alusão a Is $29,13 \mathrm{em} \mathrm{Cl} 2,22$, enquanto a Novum Testamentum Graece (ed. 27) confirma ainda como alusōes (não inclusas na Novum Testamentum Graece, ed. 28): a Pr 8,23-27 em Cl 1,17; a Sl 110,1 em Cl 3,1; e a Gn 1,26-28 em Cl 3,10.

\section{Análise das passagens}

Pode-se observar que as seguintes passagens são predominantes na análise dos quatro estudiosos destacados na tabela (considerando-se pelo menos três mençóes): "dar frutos e crescer", Gn 1,26-28, em Cl 1,6.10.15; 3,9-10; Ex 31,3; 35,31-32; Is 11,2.9, em Cl 1,9-10; o "motivo do êxodo", em Cl 1,12-14; $2 \mathrm{Sm}$ 7,12-16, em Cl 1,13; Sl 89,27 [LXX 88,28], em Cl 1,15; o tema da sabedoria ou Pr 8,22-31, em Cl 1,15-2065; Sl 68,16 [LXX 67,17], em Cl 1,19; Dt 30,6, em Cl 2,11; Gn 17,10-27, em Cl 2,13; Is 29,13, em Cl 2,22; e Sl 110,1, em Cl 3,1.

Esses textos serão, portanto, analisados resumidamente a seguir, indicando a fonte que, em sua maioria, vem da LXX, pois Paulo escreve em grego e é mais que natural que ele use a Septuaginta como fonte ${ }^{66}$. Mas, algumas vezes, ele também usa o texto hebraico ou mesmo outras fontes que nem sempre conseguimos descobrir ${ }^{67}$.

Gn 1,26-28 é o texto mais usado na Carta aos Colossenses e o mais reconhecido como referência pelos comentaristas. Gn 1,28, pela LXX, compartilha com Cl 1,6.10

\footnotetext{
${ }^{64}$ Nestle-Aland, Novum Testamentum Graece (ed. 27).

${ }^{65}$ Segundo Buscemi, Una Sinfonia. Gli Inni di Paolo a Cristo Signore, 56-60, existe uma ligação muito profunda entre os textos sapienciais e o hino de Cl 1,15-21. Ele elenca três: Pr 8,22-31; Eclo 24,3-12 e $\mathrm{Sb} 7,22-8,1$. Buscemi traça um paralelo temático entre o hino paulino e estes três textos sapienciais, realçando seus vários aspectos que ele vê como confluentes.

${ }^{66}$ Silva, "Antigo Testamento em Paulo", 76.

${ }^{67}$ Ibid., 78-79.
} 
uma concordância tanto verbal quanto conceitual, mantendo uma similaridade linguística muito grande ${ }^{68}$. Ambos utilizam " $\alpha \dot{\jmath} \xi \dot{\alpha} v \omega /$ aumentar" e xaí (e), e o uso de dois sinônimos: (1) a raiz פרה presente no texto hebraico ${ }^{69}$, é traduzida na LXX por

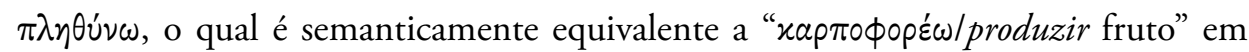

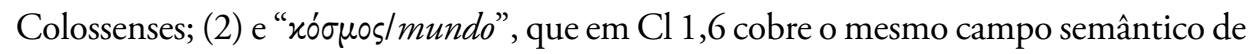
" $\gamma \tilde{\eta} /$ terra”, em Gn 1,28. Ambos os textos enfatizam o aumento e a expansão mundial mediante o imaginário do crescimento botânico, salientando que "uma nova criação foi inaugurada com os fiéis, por causa da identificação deles com Cristo" ${ }^{\text {" }}$.

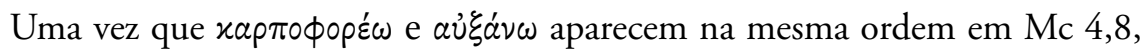
é possível que a referência ao texto de Gênesis tenha sido mediada pela tradição da Igreja ao escritor de Colossenses ${ }^{71}$. O mandato de Gn 1,28 - o primeiro dos 613 mandamentos segundo a tradição judaica - repete-se por todo o Antigo Testamento, concluindo-se então que "os fiéis são a descendência criada do último Adão, que estão começando a cumprir nele o mandato conferido ao primeiro Adão"72.

Beetham aponta ainda em $\mathrm{Cl}$ 1,9-10 um eco de Is 11,2.9: a expressão " $\pi \nu \varepsilon \tilde{\mu} \mu$

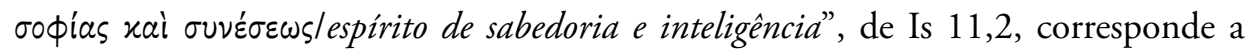

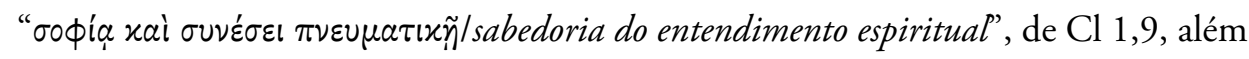

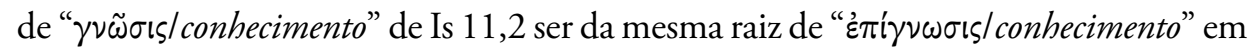
$\mathrm{Cl}$ 1,9; há ainda a rara similaridade conceitual de Deus estar preenchendo o mundo com o conhecimento de si mesmo através do seu Espírito e da figura messiânica ${ }^{73}$. Beale analisa que poderia se entender uma alusão não somente à passagem de Is 11,2.9, mas também a Ex 31,3; 35,31-32, uma vez que mantém em comum com $\mathrm{Cl} 1,10$ o resultado desse preencher também como cumprimento da vontade de Deus

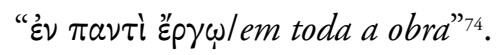

\footnotetext{
${ }^{68}$ Schweizer, La Carta a los Colosenses, 41.

${ }^{69}$ Kittel (ed.), Biblia Hebraica Stuttgartensia. dos colossenses, que ela nos ajuda a perceber de forma magistral (cf. 1999, 102-116).

${ }^{72}$ Beale, "Colossenses", 1042-1044.

${ }^{73}$ Beetham, Echoes of Scripture in the Letter of Paul to the Colossians, 61.

${ }^{74}$ Beale, "Colossenses”, 1046.
}

${ }^{70}$ Beale, "Colossenses", 1040-1041; Beetham, Echoes of Scripture in the Letter of Paul to the Colossians, 41.

${ }^{71}$ Sumney, "Writing 'In the Image' of Scripture: The Form and Function of References to Scripture in Colossians", 190. Sobre a tradição da Igreja dos colossenses, inclusive oral, indicamos a obra Standhartinger, Studien zur Entstehungsgeschichte und Intention des Kolosserbriefs, onde a autora realiza um estudo sobre as origens e intençôes da Carta aos Colossenses, apresentando um estudo sobre a razão e a intenção da mesma (cf. 1999, 16-26), e, em seguida, levanta a temática da tradição oral paulina, tocando no tema em Paulo (seu epistolário) e na Carta aos Colossenses, ou seja, na tradiçáo da comunidade 
Entretanto, Isaías era mais utilizado como texto messiânico no início da era cristã do que a passagem de Êxodo - o qual seria obscuro, por comparação; e há em Is 11,2 o mesmo imaginário da nova criação já abordado através do eco de Gn 1,28. Que o tema criacional também está presente em Is 11,1-9 fica evidente pela citação deste em Is $65,25^{75}$. Gn 1,28 e Is 11,2 ainda mantêm em comum a metáfora botânica aplicada ao crescimento humano ${ }^{76}$. Há uma nova aplicação em Colossenses que diferencia daquela em Isaías: não apenas Cristo estará pleno de conhecimento, mas os membros da Igreja devem também estar repletos desse conhecimento, um "choque de reconhecimento" da transformação almejada ${ }^{77}$.

Embora seja pouco provável que se tenha em mente alguma passagem específica do Antigo Testamento, o "motivo do êxodo" parece ter influenciado o vocabulário de Cl 1,12-1478. Beetham começa sua análise em Dt 10,9, mediante os vocábulos " $\mu \varepsilon p i ́ s /$ porção" e " $x \lambda$ ñpos/herança", e Ex 14,30, mediante o verbo ṕúoual, salientando que a ênfase para o texto de Colossenses não encontra-se na menção aos levitas, e sim ao fato de que as demais tribos realmente receberam sua parte na herança da terra de Israel 7 . Sumney salienta a "combinação de imagens" que parece aludir primariamente a Ex 6,6-8, embora também encontre ecos na aliança davídica em $2 \mathrm{Sm} 7,12-14^{80}$. Como Beale pontua, provavelmente o povo de Deus em Cristo é visto "sofrendo um êxodo semelhante ao do Egito, porém numa escala bem maior, que teve início espiritualmente nesta era e será consumado na ressurreição física" ${ }^{81}$.

É a evocaçáo do tema do "segundo êxodo", conforme atestado em Ed 9 e $\mathrm{Ne}$ 9. Entretanto, uma vez que estas restauraçóes do exílio babilônico foram incompletas, parciais, entende-se que o cumprimento cabal ocorreu com os colossenses, libertados do domínio das "trevas" e transferidos para o reino de seu Filho Jesus - o tema da "herança na luz", em Cl 1,12, remete a várias passagens das Escrituras referindo-se à presença da glória divina como "luz" ${ }^{82}$.

\footnotetext{
${ }^{75}$ Beetham, Echoes of Scripture in the Letter of Paul to the Colossians, 65-66.

${ }^{76}$ Beale, "Colossenses", 1047.

${ }^{77}$ Sumney, "Writing 'In the Image' of Scripture: The Form and Function of References to Scripture in Colossians", 192.

${ }^{78}$ Beale, "Colossenses", 1048.

${ }^{79}$ Beetham, Echoes of Scripture in the Letter of Paul to the Colossians, 81.

${ }^{80}$ Sumney, "Writing 'In the Image' of Scripture: The Form and Function of References to Scripture in Colossians", 194.

${ }^{81}$ Beale, “Colossenses”, 1049.

${ }^{82}$ Beetham, Echoes of Scripture in the Letter of Paul to the Colossians, 85-92.
} 
Na mesma perícope de $\mathrm{Cl}, 12-14$, passa-se para o eco à aliança davídica conforme

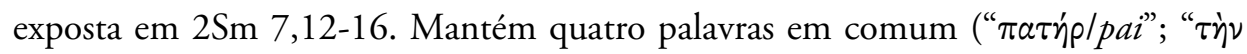

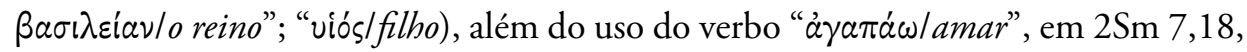

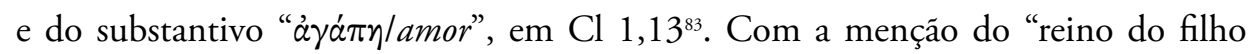
amado" procura-se salientar que a promessa se cumpriu parcialmente em Salomão e totalmente em Cristo ${ }^{84}$.

$\mathrm{Na}$ verdade, a linguagem ainda lembra o tema do êxodo visto anteriormente, pois Deus, o Pai, redimiu os colossenses da escravidão do "domínio das trevas" e transportou-os para o "reino do seu Filho amado", usando a linguagem pactual e os títulos reais da linhagem davídica. A menção ao texto de 2 Samuel poderia ter sido mediada pela tradição da Igreja, conforme atestado em Mc 1,11, Mt 3,17 e Lc 3,22 ${ }^{85}$.

O "hino cristológico" de Cl 1,15-20, o mais discutido pelos comentaristas do que qualquer outra passagem da carta ${ }^{86}$, entrelaça a alusão ao "tema da sabedoria" (cf. Pr 8,22-31) com diversos ecos: retoma Gn 1,26-28 para falar de Jesus como a “imagem de Deus", o primogênito (cf. Sl 89,27 [LXX 88,28] e Ex 4,22-23), em Cl 1,15; e a habitação de Deus em Cristo, com Sl 68,16 [LXX 67,17], ecoando em Cl 1,1987.

$\mathrm{O}$ "tema da sabedoria" perpassa toda a passagem ${ }^{88}$; não alude stricto sensu diretamente a $\operatorname{Pr} 8$ e sim através do desenvolvimento interpretativo do primeiro século da Era Cristá: descrevendo Cristo numa linguagem tipicamente usada em relação à sabedoria, personificada como sentada à destra de Deus antes e durante o trabalho na criaçãa ${ }^{89}$. Esta sabedoria personificada aparece, por exemplo, em Sb 1, 4-11 e 6,12 - 11,1, com atenção especial a 9,1: se Deus permanece a fonte primária da criação, "tudo criou pela sua palavra", ou seja, pela sua Sabedoria. E é notável que em $\mathrm{Cl} 1,15-20 \pi \tilde{\alpha} \varsigma$ seja utilizado oito vezes para descrever a natureza e atividade de Cristo ${ }^{\circ}$.

Embora o texto possa ser analisado sob diversos aspectos, concordamos com Aletti, ao afirmar que a grande maioria dos comentadores não tem dúvidas em falar de $\mathrm{Cl}$ 1,15-20 como "um hino", inclusive com possibilidade de fontes pré-paulinas ${ }^{11}$.

\footnotetext{
${ }^{83}$ Ibid., 97.

${ }^{84}$ Beale, "Colossenses", 1050.

${ }^{85}$ Beetham, Echoes of Scripture in the Letter of Paul to the Colossians, 108-110.

${ }^{86}$ Beale, "Colossenses", 1051.

${ }^{87}$ Sumney, "Writing 'In the Image' of Scripture: The Form and Function of References to Scripture in Colossians", 197; Schweizer, La Carta a los Colosenses, 65.

${ }^{88}$ Buscemi, Una Sinfonia. Gli Inni di Paolo a Cristo Signore, 56.

${ }^{89}$ Beetham, Echoes of Scripture in the Letter of Paul to the Colossians, 113-114.

90 Ibid., 120-121.

${ }^{91}$ Aletti, Lettera ai Colessesi, 84.
} 
Uma temática criacional, além da sapiencial, fica evidente ainda pela tradução para $\operatorname{Pr}$ 8,22: "YHWH me criou, princípio de seu caminho!" 92 Por isso, a retomada de Gn 1,26-28 para se falar de Cristo como a imagem de Deus: ainda que reflita a cristologia do "novo Adão", haveria a intenção de aplicar tudo o que foi dito acerca da sabedoria a Cristo, ao mesmo tempo que olhando de relance as interpretações das narrativas da criação em Gênesis ${ }^{93}$.

De fato, Filon de Alexandria descreve a sabedoria como a "imagem de Deus", citando claramente Gn 1,26-28; e também aplica-lhe o título "primogênito" ${ }_{44}$ - o que explicaria a menção de Sl 89,27 [LXX 88,28] e Ex 4,22-23. A ênfase encontra-se no status de Cristo, comparando-o ao descendente davídico na sua posição como o rei mais elevado na terra de Israel.

A temática sapiencial é concluída com o eco de Sl 68,16 [LXX 67,17], garan-

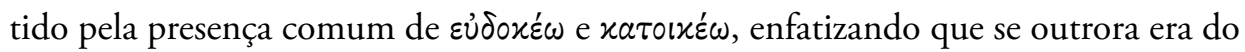
agrado de Deus habitar no monte Sião, agora mudou sua morada para Cristo, em toda sua plenitude ${ }^{95}$. No judaísmo antigo, a sede tradicional da sabedoria era o Templo de Jerusalém, conforme atestado em Eclo 24; portanto, em Cristo inaugura-se o templo escatológico, em que a plenitude e a sabedoria de Deus começaram a habitar ${ }^{96}$.

Em Cl 2,11 muda-se para a temática da circuncisão, com eco de Dt 30,6. Há também um desvio do padrão seguido até aqui de usar a Septuaginta bem de perto: a correspondência verbal está mais de acordo com o texto hebraico, ou através de Áquila,

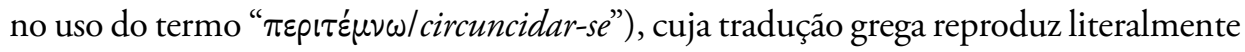

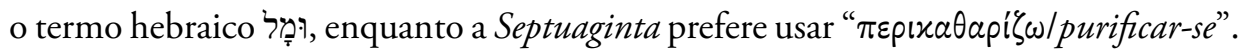

O ponto primordial é que ambos os textos compartilham a similaridade conceitual única de uma circuncisão realizada divinamente: enquanto outros textos falam da circuncisão ou incircuncisão do coração (cf. Lv 26,41; Dt 10,16; Jr 4,4; 9,25-26), somente Dt 30,6 menciona Deus diretamente efetuando uma circuncisão ${ }^{97}$.

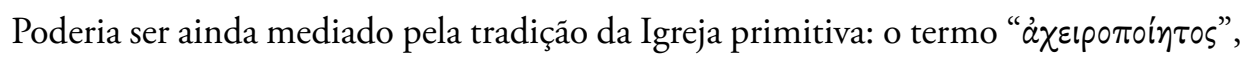
que significa "não feito por mão”, aparece somente em Mc 14,58; 2Cor 5,1 e Cl 2,11,

\footnotetext{
${ }^{92}$ Beetham, Echoes of Scripture in the Letter of Paul to the Colossians, 115-117.

${ }^{93}$ Sumney, "Writing 'In the Image' of Scripture: The Form and Function of References to Scripture in Colossians", 198.

${ }^{94}$ Beetham, Echoes of Scripture in the Letter of Paul to the Colossians, 125-126.

${ }^{5}$ Sumney, "Writing 'In the Image' of Scripture: The Form and Function of References to Scripture in Colossians", 199-200.

${ }^{96}$ Beale, "Colossenses", 1058.

${ }^{97}$ Beetham, Echoes of Scripture in the Letter of Paul to the Colossians, 157.
} 
e não na Septuaginta; e o uso metafórico da circuncisão também é atestado em Fl 3,3; Rm 2,28-29 e 2Cor 3,3.

É uma difícil interpretação acerca do batismo cristão, uma vez que os gentios geralmente não reputavam a circuncisão como algo bom. $\mathrm{O}$ uso dessa metáfora e a mudança da segunda pessoa do plural para a primeira pessoa do plural no meio de $\mathrm{Cl}$ 2,13 sugere que o autor de Colossenses seja de fato judeu, enquanto seus ouvintes-leitores não ${ }^{98}$.

$\mathrm{Na}$ interpretação judaica, gentios eram considerados impuros, enquanto os judeus eram incircuncisos no coração. Uma vez que este tipo de circuncisão era esperada para o final dos tempos ${ }^{99}$, os cristãos agora cumprem escatologicamente essa expectativa, inseridos plenamente na aliança outrora prometida com exclusividade a Israel. Isto será melhor esclarecido e complementado pelo eco de Gn 17,10-27 em $\mathrm{Cl}$ 2,13: a expressão "incircuncisão da carne" ainda é compartilhada por outros textos na Septuaginta, como Lv 12,3 e Jt 14,10. O ponto central é a identificação do status anterior dos leitores não judeus, cuja "incircuncisão" sinalizava sua alienação do pacto estabelecido por Deus ${ }^{100}$.

É a descrição de um estado "espiritual”, antes do que físico: em $\mathrm{Cl}$ 2,13 há

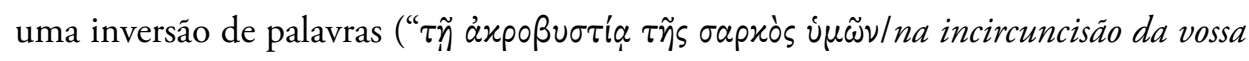

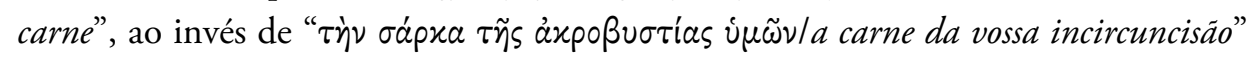
em Gn 17,11, por exemplo), uma sutileza aparentemente intencional que não mexe substancialmente no sentido original, mas que pretenderia realçar esse estado ${ }^{101}$.

Em Cl 2,22 numerosos estudiosos detectam um eco de Is 29,13, mediante

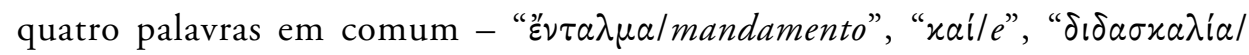
ensinamento", " $\alpha \nu \rho \omega \pi \circ /$ homem" - ainda que numa ordem ligeiramente modificada para obter um "grego melhor": enquanto no hebraico há um verbo, permitindo a tradução "mandamento humano aprendido", a Septuaginta usa o substantivo

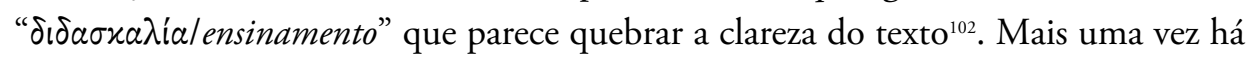
a importância da mediação pela tradição da Igreja, uma vez que o texto de Isaías é

\footnotetext{
98 Sumney, "Writing 'In the Image' of Scripture: The Form and Function of References to Scripture in Colossians", 201-202.

99 Beetham, Echoes of Scripture in the Letter of Paul to the Colossians, 170-171.

${ }^{100}$ Sumney, "Writing 'In the Image' of Scripture: The Form and Function of References to Scripture in Colossians", 203-204.

${ }^{101}$ Beetham, Echoes of Scripture in the Letter of Paul to the Colossians, 189.

102 Ibid., 193.
} 
citado formalmente em Mt 15,8-9 e Mc 8,6-7103. O contexto é o mesmo: condenar ensinamentos alheios à doutrina puramente cristã ${ }^{104}$.

O texto dos Evangelhos especifica que os ensinamentos dos fariseus são mandamentos humanos, como no contexto original isaiano em que o profeta lamenta a religião israelita não ser um conhecimento pessoal de Deus e sim um conjunto de normas convencionais aprendidas mecanicamente ${ }^{105}$. Da mesma forma, o ensinamento dos proponentes da "filosofia": pela menção anterior em $\mathrm{Cl}$ 2,16 de "festas, lua nova e sábados", fica claro que tem-se em mente a lei mosaica, aparentemente defendida por uma minoria que "julga" a maioria pela não observância desta mesma lei ${ }^{106} . \mathrm{O}$ texto isaiano estaria sendo utilizado de maneira analógica: assim como Israel no passado, os crentes-judeus estariam "idolatrando" o ritualismo judaico como conditio sine qua non para a comunidade cristãa ${ }^{107}$.

Em Cl 3,1 encontra-se um eco de Sl 110,1 - o texto do Antigo Testamento mais utilizado pelos escritores do Novo Testamento ${ }^{108}$, ou "mais citado no Novo Testamento"109, sobretudo em temas cristológicos ${ }^{10}$. Sáo numerosos os estudiosos que veem essa relação entre estes dois textos, que possuem três palavras em comum

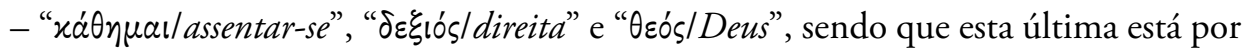

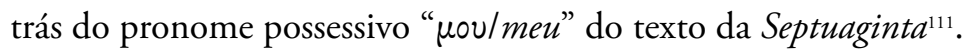

Geralmente as referências no Novo Testamento estão relacionadas à posição exaltada de Cristo no céu, como resultado da ressurreição; a noção de um governo inaugurado também se ajusta ao contexto imediato ${ }^{112}$. Uma vez que os Evangelhos mostram o próprio Senhor Jesus citando este salmo para falar de sua messianidade

\footnotetext{
${ }^{103}$ Schweizer, La Carta a los Colosenses, 145.

${ }^{104}$ Sumney, "Writing 'In the Image' of Scripture: The Form and Function of References to Scripture in Colossians”, 207-208.

${ }^{105}$ O'Brien, Colossians, Philemon, 151.

${ }^{106}$ Beetham, Echoes of Scripture in the Letter of Paul to the Colossians, 197-198.

${ }^{107}$ Beale, "Colossenses", 1064

${ }^{108}$ Sumney, "Writing 'In the Image' of Scripture: The Form and Function of References to Scripture in Colossians", 209; Proença, "O Uso do Antigo Testamento pelo Novo Testamento", 86.

${ }^{109}$ Schweizer, La Carta a los Colosenses, 151.

${ }^{110}$ Del Páramo, "Las citas de los Salmos en San Pablo", 231.

${ }^{111}$ Beetham, Echoes of Scripture in the Letter of Paul to the Colossians, 219.

${ }^{112}$ Beale, "Colossenses", 1067.
} 
(cf. Mt 22,44; Mc 12,36; Lc 20,41-44), a Igreja primitiva reconhecia como uma confissão de fé fundamental ${ }^{113}$.

O pano de fundo "guerreiro" do Sl 110 fornece aos crentes colossenses a certeza de que, apesar do real perigo da "filosofia" ainda presente, a vitoriosa exaltação de Cristo à destra de Deus nos céus e a "teologia da união" entre os fiéis e Cristo garante que estes estấo escondidos, ou seja, "protegidos" com Cristo em Deus ${ }^{114}$.

A referência a Gn 1,26-28 retorna pela última vez na parte parenética em $\mathrm{Cl}$ 3,9-10, a qual Beetham enfatiza ser não um eco, e sim uma alusão. Ambos os textos

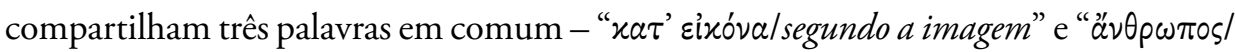

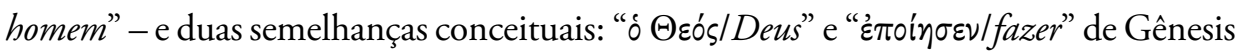

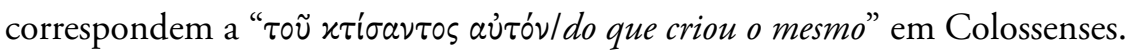

A comparação Adão-Cristo emprega a linguagem do homem "velho" e "novo" numa ótica histórico-redentiva ${ }^{115}$. O homem recriado à imagem de Deus é uma pessoa escatológica, em processo de conformação às expectativas éticas: a tensão criada entre Gn 1,26 apontando para uma único ato criativo e Colossenses abordando uma contínua renovação do homem recriado expressa a escatologia parcialmente realizada, o "já-ainda não" tipicamente paulino" ${ }^{116}$.

A menção do despir-se do velho homem e vestir-se o novo pode refletir uma prática no rito batismal ou mesmo uma alusão a Gn 3,7-21 117. É a "teologia da imagem da imagem": se Cristo é a imagem de Deus conforme Cl 1,15, os crentes são recriados tendo Cristo como padrão, modelo, tipologicamente o cabeça e protótipo da nova humanidade da nova criação ${ }^{118}$.

${ }^{113}$ Sumney, "Writing 'In the Image' of Scripture: The Form and Function of References to Scripture in Colossians", 210.

${ }^{114}$ Beetham, Echoes of Scripture in the Letter of Paul to the Colossians, 227.

115 Ibid., 231.

${ }^{116}$ Sumney, "Writing 'In the Image' of Scripture: The Form and Function of References to Scripture in Colossians", 210-212.

117 Beale, "Colossenses", 1069-1070.

${ }^{118}$ Beetham, Echoes of Scripture in the Letter of Paul to the Colossians, 242-244. 


\section{Análise retórica bíblica semítica"19}

Com relação às seções da Carta aos Colossenses - segundo a Análise Retórica Bíblica Semítica -, a saudação inicial $(1,1-2)$ pode formar junto com a oração inicial (1,3-11) uma "introdução epistolar" ${ }^{120}$, da mesma forma que a exortação final $(4,2-6)$ pode formar, junto com a saudação final (4,7-18), uma "conclusão epistolar". Além da equivalência lógica entre a introdução (1,1-11) e a conclusão epistolar (4,2-18), a seção "doutrinária" gira em torno do tema "obras" - mais especificamente, o que Cristo fez por nós -, enquanto a seção "parenética" gira em torno do que o cristão faz em Cristo, evidenciando a centralidade da conclusão doutrinária:

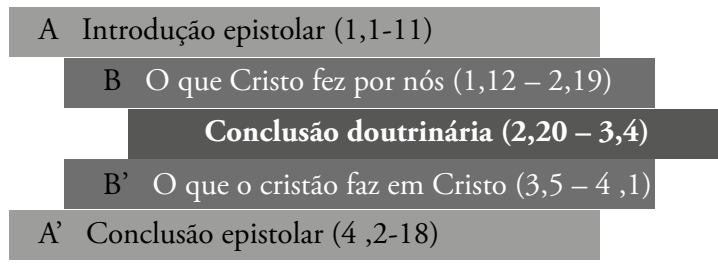

Levando em consideração as sequências, detecta-se a seguinte disposiçáo retórica: a saudação inicial (1,1-2) contrapôe-se à saudação final (4,7-18); a exortação final (4,2-6), incluindo um apelo à perseverar em oração, corresponde à oração inicial (1,3-11); a "nova vida" em Cristo $(3,5-4,1)$ é proporcionada pela obra de Cristo descrita em 1,12-23; a atuação dos proponentes da "heresia colossense" (2,6-19) é combatida pela obra dos apóstolo descrita em 1,24-2,5. Com a única pergunta da carta indicando a conclusão doutrinária em 2,20-3,4, temos o típico centro segundo a Análise Retórica Bíblica Semítica, sustentando a mensagem do texto tal qual a Menorah judaica"12. Entretanto, isto representará uma "quebra" na

${ }^{119}$ Para uma análise do ponto de vista do "criticismo retórico", com pressupostos metodológicos diferentes daqueles colocados por Roland Meynet, indicamos conferir o texto da tese de Copenhaver, Reconstructing the Historical Background of Paul's Rhetoric in the Letter to the Colossians, 81-143, onde o autor tenta reconstruir um panorama da retórica de Paulo na Carta aos Colossenses, diante do contexto em que o apóstolo estava vivendo ao escrever esta sua carta aos cristãos de Colossos, como que numa "retórica de oposiçáo", contrastando as práticas que eles tinham com as de Cristo, que ele estava anunciando a eles, inclusive com várias admoestaçóes e advertências, visto que ele tinha que lidar contemporaneamente com o judaísmo e com religióes pagãs. Diante de tudo isso, Copenhaver busca demonstrar que a Carta aos Colossenes assume, justamente, uma nova relaçáo diante deste contexto histórico que Paulo encontra na comunidade e história de Colossos.

${ }^{120}$ Boring, Introdução ao Novo Testamento. História, literatura e teologia. Vol. 1. Questöes introductórias do Novo Testamento e escritos paulinos, que mantém 4,2-6 fora da conclusão epistolar.

${ }^{121}$ Gonzaga, "O Salmo 150 à luz da Análise Retórica Bíblica Semítica”, 159-161. 
sequência, "deslocando" a menção à obra da "heresia colossense" para depois da conclusão doutrinária:

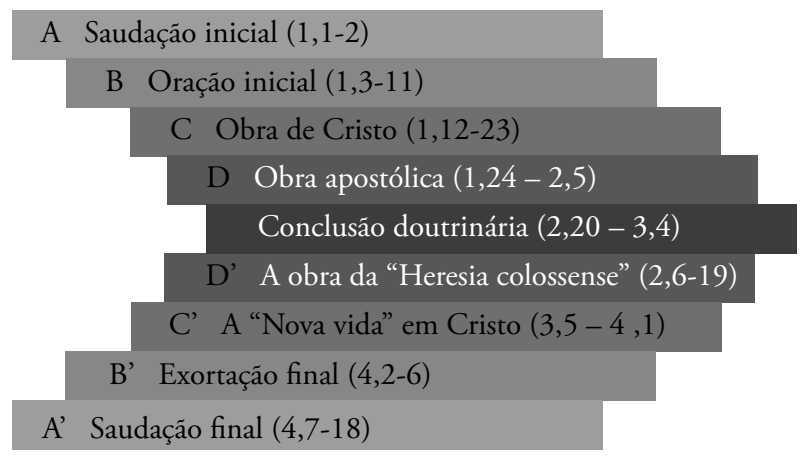

Este "deslocamento" do centro retórico da posiçẫo que seria esperada reflete um "vai e vem" na carta, no qual certos termos criam "ganchos retóricos" entre as diversas sequências:

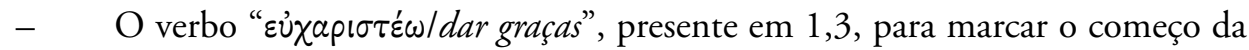
oração inicial, retorna em 1,12, para introduzir a obra através do Filho.

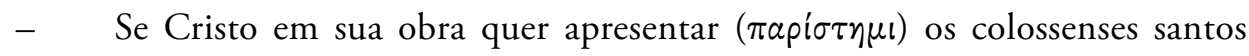
(cf. 1,22), o apóstolo quer apresentar todo homem perfeito em Cristo $(1,28)$.

- O mistério se manifestou (фavepów, cf. 1,26) para que Cristo se manifeste escatologicamente (cf. 3,4); se o mistério (cf. 1,26) e os tesouros do conhecimento (cf. 2,3) estiveram ocultos (åmoxpú $\pi \tau \omega)$, agora temos acesso pela ressurreição à esta vida oculta juntamente com Cristo, em Deus (cf. 3,3).

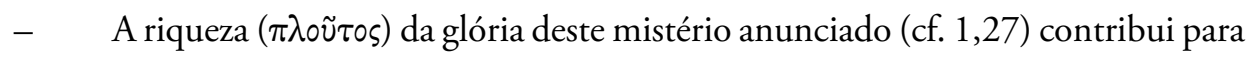
a riqueza da plena convicção do entendimento (cf. 2,2).

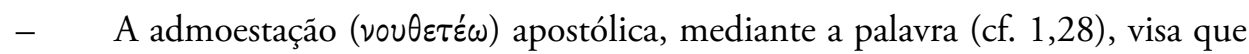
os colossenses repliquem essa atitude mutuamente (cf. 3,16).

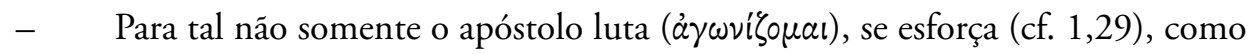
também Epafras (cf. 4,12).

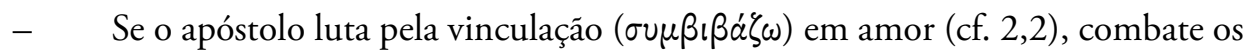
erros para que todo o corpo - a Igreja - esteja bem vinculada, através de suas juntas e ligamentos ( $\sigma \dot{\nu} \delta \delta \sigma \mu \circ$ ) (cf. 2,9) - mas o "ligamento perfeito" não é outro senão o amor (cf. 3,14).

- Adverte-se contra os "elementais" ( $\sigma \tau о\llcorner\chi \varepsilon \tilde{\alpha})$ do mundo (cf. 2,8), para os quais morreram com Cristo (cf. 2,20). 


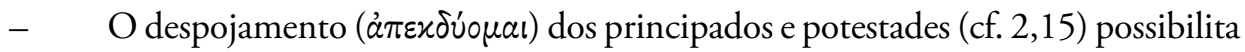
o despojamento do "velho homem" (cf. 3,9).

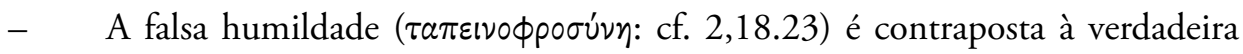
humildade cristã (cf. 3,12).

Estes "termos", os quais podemos chamar também de "ganchos retóricos", são igualmente detectados nas perícopes que compōem as diferentes sequências: na relação entre a obra e a nova vida de Cristo, a redenção $(1,12-14)$ proporciona o abandonar da velha natureza (3,5-11); o hino cristológico, enfatizando a primazia de Cristo e seu papel na "nova criação" $(1,15-20)^{122}$, permite o revestimento do cristão $(3,12-17)$; e a reconciliação explicada em 1,21-23 reflete-se nas boas relações familiares recomendadas em 3,18 - 4,1. Na contraposição entre a obra apostólica e a obra dos proponentes da "heresia colossense", o anúncio do mistério em 1,24-29 é explicado como a "nova circuncisão" em 2,6-15 e a "luta" pelos colossenses anunciada em 2,1-5 é contra a "velha circuncisão" descrita em 2,16-19.

Tabelando as alusóes e ecos nas diferentes perícopes identificadas na disposição retórica, observa-se a seguinte distribuição:

\begin{tabular}{|l|l|}
\hline $\begin{array}{l}\text { PERÍCOPES EM } \\
\text { COLOSSENSES }\end{array}$ & INTERTEXTUAL DO AT \\
\hline $\mathrm{Cl} 1,3-11$ & "Palavra da Verdade"; Gn 1,28; Ex 31,3; 35,31-32; Is 11,2.9 \\
\hline $\mathrm{Cl} 1,12-14$ & Motivo do êxodo; 2Sm 7,12-18 \\
\hline $\mathrm{Cl} 1,15-20$ & $\begin{array}{l}\text { Gn 1,1.26-28; Ex 4,22-23; Sl 68,16-17 [LXX 67,16-17]; Sl 89,27 [LXX } \\
88,28] ; \text { tema da sabedoria; Pr 8,22-31 }\end{array}$ \\
\hline $\mathrm{Cl} 1,21-23$ & $?$ \\
\hline $\mathrm{Cl} 1,24-29$ & Dn 2 \\
\hline $\mathrm{Cl} 2,1-5$ & Dn 2; Pr 2,3-6 \\
\hline $\mathrm{Cl} 2,6-15$ & Gn 17,10-27; Dt 30,6; Ez 44,7.9 \\
\hline $\mathrm{Cl} 2,16-19$ & Os 2,13 LXX; Ez 45,17 \\
\hline $\mathrm{Cl} 2,20-23$ & Is 29,13 \\
\hline $\mathrm{Cl} 3,1-4$ & Sl 110,1 \\
\hline $\mathrm{Cl} 3,5-11$ & Gn 1,26-28 (+ Gn 3,7-21) \\
\hline $\mathrm{Cl} 3,12-17$ & Dt 7,6-8; “Nome do Senhor" \\
\hline $\mathrm{Cl} 3,18-4,1$ & Ex 20,12; Lv 25,43-53; Dt 5,16; Sl 52,6 LXX; Ecl 5,7 \\
\hline $\mathrm{Cl} 4,2-6$ & Dn 2,8 \\
\hline
\end{tabular}

${ }^{122}$ Schweizer, La Carta a los Colosenses, 56-57. 
O tema veterotestamentário mais explorado é o criacional: das onze alusões e/ ou ecos estudados por Beetham, quatro tocam no assunto: $\mathrm{Gn}$ 1,26-18 em Cl 1,3-11. 15-20; 3,5-11 e Is 11,2.9 em Cl 1,3-11. O recurso retórico utilizado no eco de Gn 1,28 em Cl 1,6.10 busca realçar o crescimento exponencial do Evangelho através do mundo e uma tipologia para a nova criação inaugurada em Cristo (cf. Gl 6,15; 2 Cor 5,17$)^{123}$.

Além disso, a correspondência confirma a ligação retórica detectada supra: a oração apostólica (Cl 1,3-11) para que os colossenses sejam plenos do conhecimento da obra de Cristo $(\mathrm{Cl} 1,15-20)$ concretiza-se na vida cotidiana destes $(\mathrm{Cl} 3,5-11)$. O "velho homem" em $\mathrm{Cl}$ 3,9 é o "corpo de carne" de $\mathrm{Cl}$ 2,11, o corpo herdado de Adão, removido pela circuncisão divina ${ }^{124}$. Esta circuncisão ocorre metaforicamente no momento de crer em Cristo, algo realizado definitivamente - algo indicado pelo

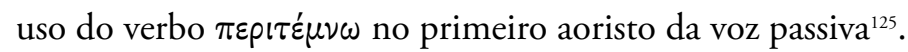

Deste modo, o eco de Is 11,2 em Cl 1,9, com sua exortação aos colossenses para serem cheios do conhecimento de Deus, visa encorajá-los a resistir a qualquer tentação de sucumbir diante da "filosofia" $(\mathrm{Cl} 2,2-4.8)$, algo possível pela sua união com Cristo, fonte maior de sabedoria, mas que pede sempre obediência ao projeto do Pai ${ }^{126}$. Jesus é o cabeça, e a Igreja seu corpo $(\mathrm{Cl} \mathrm{1,18.24;} \mathrm{2,19):} \mathrm{é} \mathrm{mediante} \mathrm{esta}$ conexão que os colossenses são preenchidos pela sua "plenitude" $(\mathrm{Cl} 2,9)^{127}$. O hápax legomenon $\theta$ cót $\eta$ s, literalmente "deidade", denota a "totalidade absoluta da essência divina”, um recurso retórico que visa eliminar "as pretensóes dos falsos mestres que ensinavam a buscar a plenitude fora de Cristo" 128 .

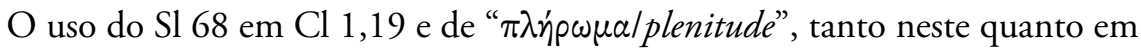
2,9, ajuda a esclarecer este último: se a divindade habita no corpo de Cristo - não meramente antes da encarnação, mas acima de tudo no homem que morreu em uma cruz - a Igreja, que é "o corpo", mediante sua união orgânica com o cabeça, a saber Cristo, está plenificada com a presença divina (cf. Cl 1,18.24; 2,19) ${ }^{129}$. Como recurso retórico possibilita-se reforçar a confiança dos colossenses na suficiência e preeminência de Cristo como revelação de Deus, e sua superioridade em relação à

\footnotetext{
${ }^{123}$ Beetham, Echoes of Scripture in the Letter of Paul to the Colossians, 59; 247.

${ }^{124}$ Ibid., 241.

${ }^{125}$ Pérez Millos, Comentario exegético al texto griego del Nuevo Testamento. Colosenses, 217.

${ }^{126}$ Schweizer, La Carta a los Colosenses, 44.

${ }^{127}$ Beetham, Echoes of Scripture in the Letter of Paul to the Colossians, 72; 78.

${ }^{128}$ Pérez Millos, Comentario Exegético al Texto Griego del Nuevo Testamento. Colosenses, 213.

${ }^{129}$ Schweizer, La Carta a los Colosenses, 73.
} 
falsa "filosofia" ${ }^{30}$. Obviamente não há um menosprezo ao conhecimento intelectual investigativo: o problema náo é a filosofia em si, e sim à filosofia contrária ou não conforme com Cristo $^{131}$.

O contexto de Dt 30,6 (30,1-10) precede a perícope de 30,11-20, a qual pode ser compreendida como o "clímax retórico" de todo o livro de Deuteronômio pela sua ênfase na chamada à uma decisão, algo importante para o Pentateuco como um todo. A chamada à "nova circuncisáo", em $\mathrm{Cl}$ 2,6-15, portanto, é uma decisão premente, a qual antecipa o "centro retórico" que inicia em $\mathrm{Cl} 2,20-23$, no qual o uso de Is 29,13 é contundente contra os proponentes da "filosofia" na Carta aos Colossenses: as estipulaçôes específicas do pacto mosaico são meros "preceitos humanos" se impostas sobre os membros da "nova aliança", e não devem ser "guardadas" coercitivamente ${ }^{132}$. A expressão " $\delta \sigma \nu \lambda \alpha \gamma \omega \gamma \tilde{\omega} \nu /$ o que escraviza", em 2,8 , fornece uma "dramática imagem" do poder desses que propagam os falsos ensinos, e Pao vê um "trocadilho desdenhoso"

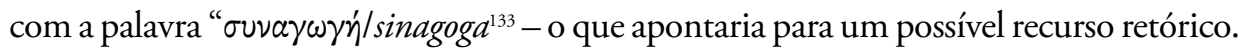

Portanto, em 3,1-4 o recurso retórico procura identificar Cristo com o prometido rei davídico de Sl 110, enquanto os inimigos deste mesmo salmo são interpretados como representados por todos os seres espirituais demoníacos que suscitam filosofias enganadoras que rivalizam com a genuína mensagem do Evangelho, o que está de acordo com a menção a $2 \mathrm{Sm} 7$, feita em $\mathrm{Cl} 1,13$.

Entretanto, aqui em $\mathrm{Cl}$ 3,1-4 o tom é mais escatológico, enfatizando o cumprimento final e definitivo do que foi anunciado anteriormente mediante $2 \mathrm{Sm} 7^{134}$. A "centralidade" retórica corresponde ao "fato central histórico da fé e esperança cristâs": Cristo ressuscitado e sentado à direita do Pai ${ }^{135}$. Isso se dá pelo fato de que em Paulo o uso da retórica "é inseparável da construção e da progressão de seus pensamentos" ${ }^{136}$.

As duas alusōes encontradas por Beetham - Pr 8,22-31 em Cl 1,15-20 (para Beale, o "tema da sabedoria") e Gn 1,26-28 em Cl 3,9-10 - providenciam uma "moldura" que confirma a disposição retórica encontrada para as seçōes, pois Gn 1,26-28 aparece como eco ainda em Cl 1,15-20. Se o termo "ả $\pi \varepsilon x \delta \cup \sigma a ́ \mu \varepsilon v o l$ l

\footnotetext{
${ }^{130}$ Beetham, Echoes of Scripture in the Letter of Paul to the Colossians, 152-156.

${ }^{131}$ Pérez Millos, Comentario Exegético al Texto Griego del Nuevo Testamento. Colosenses, 213-214.

${ }^{132}$ Beetham, Echoes of Scripture in the Letter of Paul to the Colossians, 158; 216.

${ }^{133}$ Pao, Colossians and Philemon, 158.

${ }^{134}$ Beetham, Echoes of Scripture in the Letter of Paul to the Colossians, 230.

${ }^{135}$ Del Páramo, "Las citas de los Salmos en San Pablo", 232.

${ }^{136}$ Aletti, "Uma retórica paulina: construção e comunicação de um pensamento”, 65.
} 
tendo-vos despojados", em 3,9, é entendido por muitos como um particípio imperativo, segundo Pao é melhor compreendê-lo como particípio causal adverbial, providenciando a "base" para o que foi dito previamente ${ }^{137}$. A temática "criacional" mais uma vez aponta para a centralidade de Is 29,13 e Sl 110,1 na abordagem acerca da "nova circuncisão".

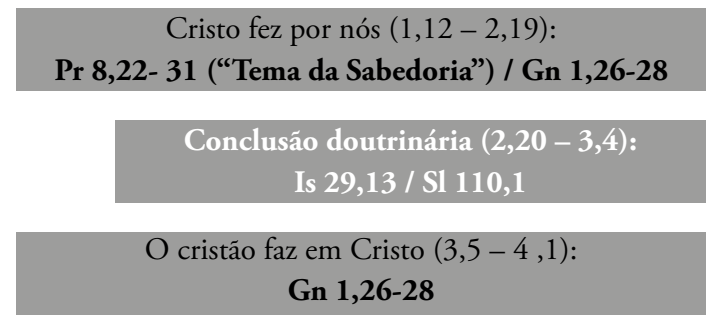

Sendo detectadas tantas alusões e ecos do Antigo Testamento, isto aponta para uma identificaçâo do caráter judaico da "filosofia" enganadora, o que faz entender que os "oponentes" são judaizantes ao extremo, no mínimo ${ }^{138}$. Isto explicaria a ausência de citaçóes explícitas do Antigo Testamento como um recurso retórico, uma vez que o autor não desejaria argumentar como um escriba utilizando a Torah, a qual poderia estar sendo usada contra o cristianismo ${ }^{139}$.

É significativo que a única passagem do Antigo Testamento utilizada possivelmente mediante o texto hebraico, e não pela Septuaginta, seja justamente Dt 30,6: o ritual da circuncisão, tão central no pensamento judaico, obtém sua real ressignificação somente com Cristo ${ }^{140}$. Por isso, embora $\mathrm{Cl} 3,18-4,1$ seja conhecido desde Lutero como Haustafel, um "código doméstico" tomado de empréstimo do contexto da cultura helênica, em especial do estoicismo, mais recentemente pesquisadores salientam como fonte o judaísmo helenista ${ }^{141}$, e as referências encontradas por Sumney (cf. tabela supra) parecem confirmar esse dado.

Entretanto, um importante recurso retórico subjaz onde na Carta aos Colossenses há ausência total, seja de citaçôes, alusóes ou ecos. Sumney identifica que seria na obra apostólica em $\mathrm{Cl}$ 1,24-2,5, onde se esperaria algum recurso à tradição veterotestamentária do sofrimento dos profetas que proclamam a palavra divina para

\footnotetext{
${ }^{137}$ Pao, Colossians and Philemon, 225.

${ }^{138}$ Beetham, Echoes of Scripture in the Letter of Paul to the Colossians, 250.

${ }^{139}$ Barth, Blanke e Beck, Colossians. A New Translation with Introduction and Commentary, 66.

${ }^{140}$ Cf. tabela em Beetham, Echoes of Scripture in the Letter of Paul to the Colossians, 275.

${ }^{141}$ O’Brien, Colossians, Philemon, 214-217.
} 
ilustrar o sofrimento apostólico pela comunidade - o autor de Colossenses parece analisar que líderes ou profetas de Israel não forneceriam uma "boa recomendação"142.

Mas aqui Beale identifica uma alusão à Dn 2 através da palavra $\mu \nu \sigma \tau$ ṕpıv, a qual é utilizada para mostrar que a profecia do Antigo Testamento está começando a se cumprir, e que esse cumprimento não era previsto pela perspectiva do Antigo Testamento ${ }^{143}$. Este mistério, outrora escondido, agora foi revelado: a participação dos gentios na riqueza da glória, ou seja, os privilégios da aliança salvífica outrora exclusiva de Israel (cf. Cl 1,26-27). Algo que náo foi anunciado ou explicado anteriormente pelos profetas e pelos escritos bíblicos, por ser algo que escapa à revelação, que a supera ${ }^{144}$ Este mistério, que supera tudo o que poderia ser dito, é a reconciliação, mencionada em Cl 1,21-23 - a passagem que de fato não possui nenhuma alusão ou eco identificado pelos estudiosos mencionados nesse artigo.

\section{Conclusão}

Duas metodologias táo distintas quanto o Uso do Antigo pelo Novo Testamento e a Análise Retórica Bíblica Semítica foram entrelaçadas para evidenciar que a ausência de citaçóes veterotestamentárias foi um recurso retórico utilizado pelo autor, no qual as alusóes e ecos são distribuídos náo de forma aleatória e sim uniforme, para brindar o leitor com um magnífico texto unindo cristologia, eclesiologia e uso do Antigo Testamento. Um método complementou e confirmou o outro, concedendo mais argumentos a Beale em detrimento de Foster na polêmica levantada.

Se a conjugação das metodologias não logrou êxito em apontar se de fato a carta é ou não autenticamente paulina, e não era esse o objetivo, sublinhou um dado: se a carta é da lavra de um paulinista, este soube magistralmente emular os recursos retóricos usados por Paulo nas suas cartas indisputadas. Mas esta mesma conjugação enfatizou como a temática da criação, marcada pelas alusóes detectadas por Beale, proporcionaram uma belíssima moldura literária para o tema central da carta: a "nova circuncisão".

\footnotetext{
${ }^{142}$ Sumney, "Writing 'In the Image' of Scripture: The Form and Function of References to Scripture in Colossians", 219. Para um histórico acerca da interpretação de $\mathrm{Cl}$ 1,24 como um "versículo sem contexto", ver o texto da Tese de Clark, Completing Christ's Afflictions: Christ, Paul, and the Reconciliation of All Things, 2-8, onde o autor faz uma análise do referido versículo indicando a dificuldade de intepretaçáo dentro do contexto da perícope desta carta deuteropaulina, indicando que $\mathrm{Cl}$ 1,24 estaria fora de contexto.

${ }^{143}$ Beale, "Colossenses", 1059.

${ }^{144}$ Belli, Carbajosa, Jódar Estrella e Sánchez Navarro, Vetus in Novo. El recurso a la escritura en el Nuevo Testamento, 203.
} 
Se o estudo apontou para a total ausência de referências veterotestamentárias na perícope acerca da reconciliação, sua possível ligação com o tema do mistério detectado por Beale na sequência da obra apostólica aponta para o caráter único desse evento, sem paralelos no Antigo Testamento. Algo que superou todas as expectativas. Ou não: haveria talvez um paralelo, usando a terminologia proposta por Beetham, de uma temática já insinuada nos livros de Rute e Jonas? Como diria Hays, qual seria o "volume" dessa intertextualidade? De qualquer forma, a Carta aos Colossenses mostra que apesar do ataque contundente às práticas judaicas impostas, isto não pressupóe nenhum "antissemitismo" de qualquer espécie, mas sim a definitiva reconciliação de todos num só corpo, tendo Cristo como cabeça. Uma contundente mensagem contra o preconceito e a intolerância tão em voga nos tempos hodiernos.

\section{Referências}

Aletti, Jean-Noël. Lettera ai Colessesi. Bologna: EDB, 1994.

. “Uma retórica paulina: construção e comunicação de um pensamento”. En Paulo, uma teologia em construção, Vários autores, 51-71. São Paulo: Loyola, 2011.

Barth, Markus; Helmut Blanke; e Astrid B. Beck. Colossians. A New Translation with Introduction and Commentary. New Haven-London: Yale University Press, 2008.

Beale, Gregory K. "Colossenses”. En Comentário do uso do Antigo no Novo Testamento, organizado por G. K. Beale e Donald A. Carson, 1039-1075. São Paulo: Vida Nova, 2014.

. Manual do uso do Antigo Testamento no Novo Testamento. Exegese e interpretação. São Paulo: Vida Nova, 2013.

- "The Old Testament in Colossians: A Response to Paul Foster". Journal for the Study of the New Testament 41/2 (2018): 261-274.

Beetham, Cristopher A. Echoes of Scripture in the Letter of Paul to the Colossians. Leiden-Boston: Brill, 2008.

Belli, Filippo; Ignacio Carbajosa; Carlos Jódar Estrella; e Luis Sánchez Navarro. Vetus in Novo. El recurso a la escritura en el Nuevo Testamento. Madrid: Encuentro, 2006.

Boring, M. Eugene. Introdução ao Novo Testamento. História, literatura e teologia. Vol. 1. Questôes introductórias do Novo Testamento e escritos paulinos. São Paulo: Paulus, 2016. 
Bujard, Walter. Stilanalytische Untersuchungen zum Kolosserbrief: als Beitrag zur Methodik von Sprachvergleichen. Göttingen: Vandenhoeck \& Ruprecht, 1973.

Buscemi, A. M.. Una sinfonia. Gli inni di Paolo a Cristo Signore. Jerusalem: Franciscan Printing Press, 2000.

Clark, Bruce T. Completing Christ's Afflictions: Christ, Paul, and the Reconciliation of All Things. Tübingen: Mohr Siebeck, 2015.

Copenhaver, Adam. Reconstructing the Historical Background of Paul's Rhetoric in the Letter to the Colossians. London: Bloomsbury T\&T Clark, 2018.

Del Páramo, Severiano. "Las citas de los Salmos en San Pablo". En Analecta biblica 17-18. Studiorum Paulinorum Congressus Internatinalis Catholicus 1961, organizado por Pontificio Instituto Bíblico, 229-241. Roma: Pontificio Instituto Bíblico, 1963.

Dunn, James D. G. The Epistles to the Colossians and to Philemon. A Commentary on the Greek Text. Grand Rapids (MI)-Carlisle: William B. Eerdmans PublishingPaternoster Press, 1996.

Fee, Gordon D. "Old Testament Intertextuality in Colossians: Reflections on Pauline Christology and Gentile Inclusion in God's Story”. En History and Exegesis. New Testament Essays in Honor of Dr. E. Earle Ellis for His 80th Birthday, organizado por S.-W. Son, 201-221. New York: T\&T Clark, 2006.

Foster, Paul. "Critiquing Certain Aspects of Recent Scholarly Trends in the Study of the Jewish Scriptures in the New Testament". Journal for the Study of the New Testament 38/1 (2015): 96-111.

Frank, Nicole. Der Kolosserbrief im Kontext des paulinischen Erbes: eine intertextuelle Studie zur Auslegung und Fortschreibung der Paulustradition. Tübingen: Mohr Siebeck, 2009.

Gonzaga, Waldecir. Compêndio do Cânon Bíblico. Listas dos Catálogos Bíblicos: Antigo Testamento, Novo Testamento e Apócrifos. Petrópolis RJ-Rio de Janeiro: Editora PUC- Vozes, 2019.

. "O Corpus Paulinum no Cânon do Novo Testamento". Atualidade Teológica 54 (2001): 19-41.

. "O Salmo 150 à luz da Análise Retórica Bíblica Semítica”. Revista Brasileira de Interpretação Bíblica 1/2 (2018): 155-170. 
Hays, Richard B. Echoes of Scripture in the Letters of Paul. New Haven-London: Yale University Press, 1989.

Kalvesmaki, Joel. Old Testament Quotations in the New Testament. Ann Arbor (MI): Cushing-Malloy Inc., 1967.

Kittel, Rudolf (ed.). Biblia Hebraica Stuttgartensia. Editio quarta emendata opera H. P. Rüger. Stuttgart: Deutsche Bibelgesellschaft, 1997.

Lohse, Eduard. Colossians and Philemon. Philadelphia: Fortress Press, 1971.

Meynet, Roland. L'Analise Retorica. Brescia: Queriniana, 1992.

. Trattato di Retorica Biblica. Bologna: EDB, 2008.

Nestle-Aland. Novum Testamentum Graece (ed. 27). Stuttgart: Deutsche Bibelgesellchaft, 1993.

. Novum Testamentum Graece (ed. 28). Stuttgart: Deutsche Bibelgesellchaft, 2012.

O’Brien, Peter T. "Cartas aos Colossenses". En Dicionário de Paulo e suas Cartas (2a. ed.), organizado por Gerald F. Hawthorne, Ralph P. Martin e Daniel G. Reid, 247-255. Sáo Paulo: Vida Nova-Paulus-Loyola, 2008. . Colossians, Philemon. Dallas (TX): Word Inc., 1998.

Pao, David W. Colossians and Philemon. Grand Rapids (MI): Zondervan, 2012.

Paulinas. A Bíblia TEB. Nova edição revista e corrigida. São Paulo: Loyola, 1995.

Paulus Editora. Bíblia de Jerusalém. Nova ed. rev e ampl. São Paulo: Paulus, 2019.

Pérez Millos, Samuel. Comentario exegético al texto griego del Nuevo Testamento. Colosenses. Barcelona: Clie, 2015.

Proença, Eduardo. "O Uso do Antigo Testamento pelo Novo Testamento". En O uso que o Novo Testamento faz do Antigo Testamento. Bíblia: introdução e hermenêutica, editado por Eduardo Proença, 83-103. São Paulo: Fonte Editorial, 2009.

Rahlfs, Alfred, e Robert Hanhart (eds.). Septuaginta. Stuttgart: Deutsche Bibelgesellschaft, 2006.

Robertson, A. W. El Antiguo Testamento en el Nuevo. Buenos Aires-Grand Rapids: Nueva Creación-William B. Eerdmans Publishing Co., 1996. 
Silva, Moisés. "Antigo Testamento em Paulo". En Dicionário de Paulo e suas Cartas (2a. ed.), organizado por por Gerald F. Hawthorne, Ralph P. Martin e Daniel G. Reid, 76-92. São Paulo: Vida Nova; Paulus; Ediçôes Loyola, 2008.

Schenk, Wolfgang, "Der Kolosserbrief in der neueren Forschung (1945-1985)". Auftieg und Niedergang der Römischen Welt 2.25.4 (1987): 3327-3365.

Schweizer, Eduard. La Carta a los Colosenses. Salamanca: Sígueme, 1987.

Standhartinger, Angela. Studien zur Entstehungsgeschichte und Intention des Kolosserbriefs. Leiden: Brill, 1999.

Sumney, Jerry L. "Writing 'In the Image' of Scripture: The Form and Function of References to Scripture in Colossians". En Paul and Scripture: Extending the Conversation, organizado por Cristopher D. Stanley, 185-229. Atlanta (GA): Society of Biblical Literature, 2012. 